\title{
Migmatite gneiss of the Jættedal complex, Liverpool Land, East Greenland: protracted high- $T$ metamorphism in the overriding plate of the Caledonian orogen
}

\author{
S. M. JOHNSTON, ${ }^{1}$ A. KYLANDER-CLARK ${ }^{2}$ AND H. K. BRUECKNER ${ }^{3}$ \\ ${ }^{1}$ Physics Department, California Polytechnic State University, San Luis Obispo, CA 93407, USA (scjohnst@calpoly.edu) \\ ${ }^{2}$ Department of Earth Science, University of California, Santa Barbara, CA 93106, USA \\ ${ }^{3}$ Lamont-Doherty Earth Observatory, Columbia University, Palisades, NY 10964, USA
}

\begin{abstract}
The Greenland Caledonides (GC) formed in the overriding Laurentian plate during the closure of the Iapetus Ocean and the subduction of Baltica, and offer a unique opportunity to study metamorphic patterns, regional structures and the kinematic evolution of the overriding plate of a continental collision. We present new metamorphic petrology and coupled zircon geochronology and geochemistry data from the Jættedal complex in southern Liverpool Land to document the thermal evolution of the orogenic core of the southern GC. Pelitic migmatite gneisses from the Jættedal complex document metamorphic conditions of $850-730{ }^{\circ} \mathrm{C}$ at pressures of $11-9.5 \mathrm{kbar}$. Zircon from these samples yields Archean-Mesoproterozoic detrital cores with positive heavy rare earth element (HREE) slopes, and 440-425 Ma rims with flat HREE slopes are interpreted to date the timing of prograde pelite anatexis. Intercalated mafic assemblages record metamorphic conditions of $860-820^{\circ} \mathrm{C}$ at $12-$ 10 kbar. Zircon from mafic gneisses contains cores with ages of c. $458 \mathrm{Ma}$ with positive HREE slopes and 413-411 Ma rims with flat HREE slopes that are interpreted to record the timing of original mafic dyke intrusion and subsequent partial melting respectively. When placed in the context of correlative rocks from the southern GC, these results suggest the development of a thermally weakened lower to middle crust in the Caledonian overriding plate that spanned $>200 \mathrm{~km}$ perpendicular to orogenic strike during the Silurian. The existing data further suggest Silurian syn-orogenic channel flow and exhumation occurred at the thrust front, while protracted high- $T$ metamorphism continued in the orogenic core. These patterns highlight variations in the thermal and rheologic structure of the Caledonian overriding plate along orogenic strike, and have implications for the development and exhumation of high- and ultrahigh-pressure terranes.
\end{abstract}

Key words: granulite facies anatexis; Greenland Caledonides; Jættedal complex; Liverpool Land; zircon petrochronology.

\section{INTRODUCTION}

The overriding plates of continental collisions are characterized by overthickened crust with thermal structures that vary through time and space, and define rheologic conditions in the lower to middle crust important for the kinematic evolution of the entire orogen. The significance of the thermal conditions in the overriding plate is emphasized by recent models applied to the Himalayan-Tibetan orogen that predict the development of melt-weakened lower crustal channels that flow outwards in response to pressure gradients leading to the lateral growth of orogenic plateaux (e.g. Bird, 1991; Royden et al., 1997), and/or the development of syn-orogenic extensional structures in the orogenic wedge (Beaumont et al., 2001). At deeper levels, the overriding plate may become an important reservoir for previously buried continental (ultra)high-pressure (U)HP terranes with implications for the formation and composition of continental crust (Hacker et al., 2011). The emplacement of (U)HP terranes into overriding plates of continental collisions may occur in intracontinental settings through subduction (Gilotti \& McClelland, 2007) or lithospheric foundering (Hacker et al., 2005), or through terrane transfer in which continental material from the subducted continental plate is relaminated to the base of the overriding plate during exhumation (Chemenda et al., 2000; Augland et al., 2011). Thermal-mechanical models further suggest that terrane transfer may be encouraged by generally weak conditions in the overriding continental plate (Butler et al., 2011). Despite the central role that the overriding plate plays in the dynamics of continental orogenesis, data describing the thermal structure of the lower to middle crust of the overriding plate are limited to seismic studies (e.g. Nelson et al., 1996; Owens \& Zandt, 1997) and 
crustal xenoliths included in orogenic volcanic rocks (Hacker et al., 2000; e.g. Gordon et al., 2012), while time-transgressive petrological and structural relationships from the lower to middle crust remain buried in active orogens. However, ancient orogens with lower to middle crust currently exposed at the surface can be exploited to characterize the thermal architecture observed within the hangingwall over the course of the orogenic cycle.

The Greenland Caledonides (GC) formed as Baltica collided with and subducted beneath Laurentia (Haller, 1971; Higgins et al., 2008), and present an extensive ancient analogue where the spatial and temporal patterns of metamorphism in the overriding continental plate can be studied. Here, metamorphic petrology and coupled zircon geochronology and geochemistry are used to document the metamorphic evolution on the Jættedal complex of southern Liverpool Land, and ultimately, the regional metamorphic trends from the orogenic core of the southern GC. The results are consistent with the development of a broad, melt-weakened lower to middle crust throughout the southern GC in the Silurian, and while this weak crust was exhumed rapidly near the thrust front, sections in the orogenic core remained hot and weak during subduction of Baltican continental crust.

\section{GEOLOGICAL BACKGROUND}

The Caledonides represent a Himalayan-scale collisional orogen formed during the Silurian closure of the Iapetus Ocean and the ultimate collision of Laurentia and Baltica during the Devonian (Gee, 1975; Roberts, 2003). The Scandinavian Caledonides consist of a series of allochthonous and parautochthonous nappes that were thrust eastwards onto the Baltican margin (Roberts \& Gee, 1985), and peridotite boudins together with widespread evidence for UHP metamorphism in the Western Gneiss Complex mark the burial of the Baltica autochthon to mantle depths beneath Laurentia by 415-400 Ma (Carswell et al., 2003; Root et al., 2004). Following burial, the Western Gneiss Complex was rapidly exhumed to upper crustal levels by 400-380 Ma (Walsh et al., 2007) during Middle Devonian regional extension of the Scandinavian Caledonides (Fossen, 2010).

The GC formed on the Laurentian continental margin and record deformation in the overriding plate above the subducted Baltican plate, although the timing and style of deformation varies considerably along strike (Fig. 1). North of $76^{\circ} \mathrm{N}$, the northern GC include a series of Devonian-Carboniferous thrust sheets that increase in metamorphic grade up structural section from weakly metamorphosed sedimentary rocks in the west to eclogite facies gneiss in the east (Gilotti et al., 2008). In contrast, south of $76^{\circ} \mathrm{N}$, the thrust architecture of the southern GC is complicated by an earlier period of Silurian high- $T$ metamorphism and a series of syn-post-orogenic extensional structures (Gilotti \& McClelland, 2008). This thrust architecture is best displayed in the western inner fjords of the southern GC from 72 to $75^{\circ} \mathrm{N}$ where the high-grade metamorphic rocks of the Niggli Spids and Hagar Bjerg thrust sheets are thrust over the unmetamorphosed sedimentary rocks of the Caledonian foreland (Higgins et al., 2004). Although the structural relationship between these high-grade thrust sheets is debated (Andresen et al., 2007), they can be differentiated based on variable intrusive, metamorphic and exhumation histories. The structurally higher Hagar Bjerg thrust sheet is characterized by the widespread development of 435-425 Ma migmatites and associated S-type granites that were rapidly exhumed by 410 Ma during a period of synorgenic extension (Hartz et al., 2001; White \& Hodges, 2002; White et al., 2002; Andresen et al., 2007). Structurally lower, the Niggli Spids thrust sheet lacks Silurian migmatites and is thought to have been exhumed following burial to high- $P$ granulite facies in Payer Land at 405 Ma (McClelland \& Gilotti, 2003; Gilotti et al., 2008).

Farther east in the orogenic core of the southern GC, similar metamorphic histories in gneiss complexes from Ardencaple Fjord, Clavering $\varnothing$ and Liverpool Land allow correlations with the highgrade thrust sheets near the thrust front (Gilotti et al., 2008). Of particular interest, the HP Liverpool Land eclogite terrane (the Tværdal complex of Johnston et al., 2010) displays characteristics indicative of Baltican continental affinity, and suggests the possibility of terrane transfer during Caledonian collision (Johnston et al., 2010; Augland et al., 2011). The Liverpool Land eclogite terrane is structurally overlain by the Jættedal complex, which consists of a series of migmatitic paragneiss and intercalated orthogneiss (Johnston et al., 2010). Structurally highest, the Hurry Inlet plutonic terrane is composed of calcalkaline plutonic rocks and associated paragneiss screens (Augland et al., 2010). In contrast to the Liverpool Land eclogite terrane, both the Jættedal complex and the Hurry Inlet plutonic terrane are linked to Laurentia by detrital zircon and the Silurian timing of pelitic metamorphism and calc-alkaline intrusives (Johnston et al., 2010; Augland et al., 2012).

The tectonostratigraphy of the southern Liverpool land gneisses is punctuated by two distinct deformation events defined by early top-S ductile fabrics in the highest structural levels of the Liverpool Land eclogite terrane that are overprinted by top- $\mathrm{N}$ ductile-brittle fabrics along the N-dipping Gubbedalen shear zone (Augland et al., 2010; Johnston et al., 2010). However, the relationship of these structural features to the tectonostratigraphy is debated: whereas maps from Augland et al. $(2011,2012)$ place both the Jættedal complex and the Hurry Inlet plutonic terrane in the hangingwall of the extensional Gubbedalen shear zone, Johnston et al. (2010) placed 


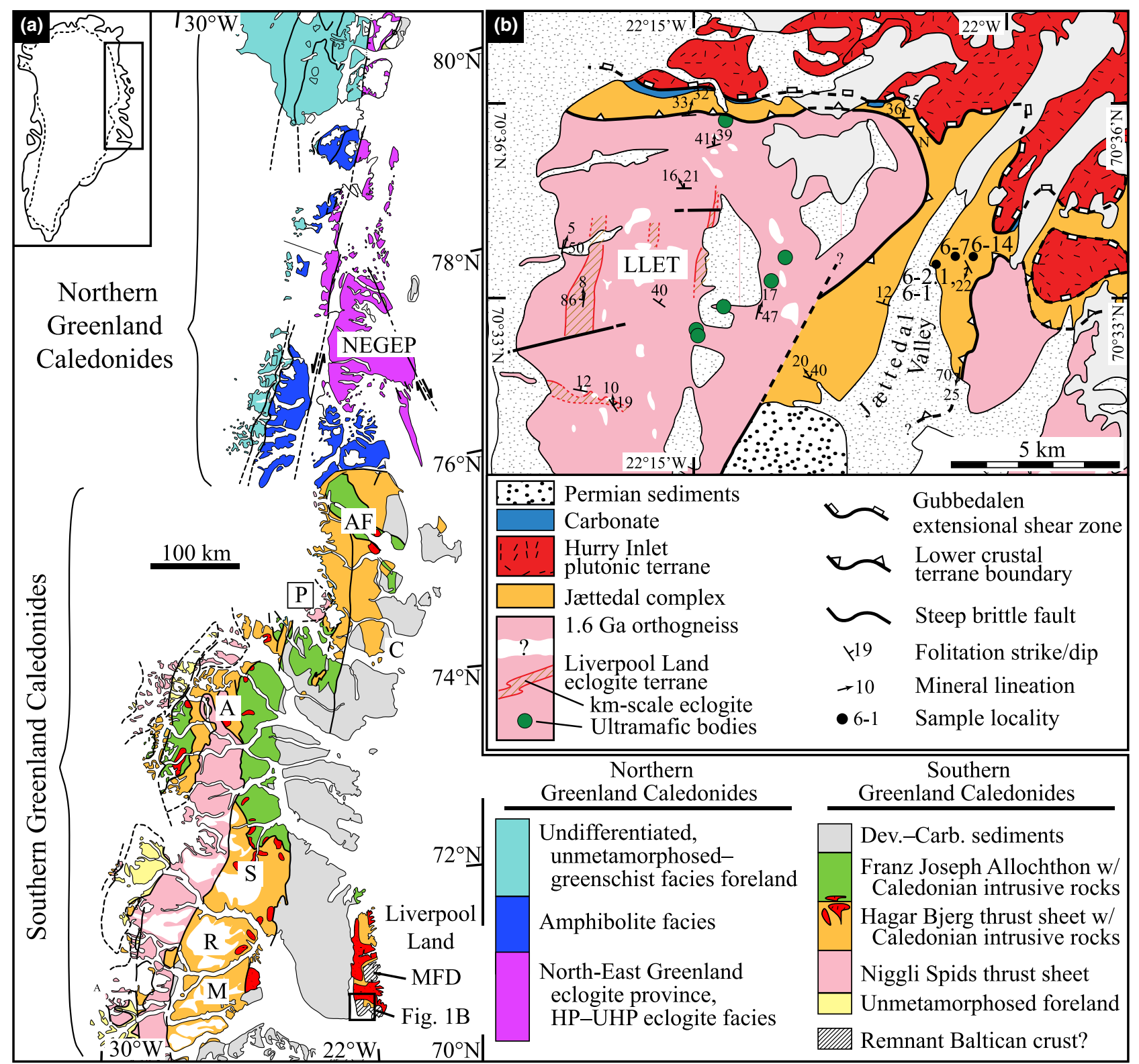

Fig. 1. (a) Regional geological map of the East Greenland Caledonides illustrating the relative locations and metamorphic patterns exposed in the northern and southern East Greenland Caledonides. Adapted from regional maps in Higgins et al. (2004) and Gilotti et al. (2008). A: Andrée Land; AF: Ardencaple Fjord; C: Clavering Ø; M: Milne Land; MFD: Marianger Fjord Dome; NEGEP: North-East Greenland eclogite province; P: Payer Land; R: Renland; S: Stauning Apler. (b) Geological map of southern Liverpool Land illustrating the petrological setting of the Jættedal complex and the locations of the investigated samples. Map after Friderichsen \& Surlyk (1981) and Johnston et al. (2010). LLET, Liverpool Land eclogite terrane.

the Jættedal complex structurally above the early top-S fabrics, but in the footwall of the extensional Gubbedalen shear zone and structurally separated from the Hurry Inlet plutonic terrane. The objective of this paper is to quantify the $P-T-t$ evolution of the Jættedal complex in order to place new constraints on the structural relationships of the southern Liverpool Land gneiss complexes, as well as to develop a better understanding of the metamorphic patterns across the width of the southern GC.

\section{METAMORPHIC PETROLOGY}

This investigation focuses on anatectic pelitic and mafic gneisses that are exposed along the eastern wall of Jættedal Valley (Fig. 1b). Here, the Jættedal Complex consists of alternating rock units that are tens of metres thick and variably composed of metapelite with rare carbonate, mafic gneiss and granitic orthogneiss. Metamorphic foliation dips moderately to the west throughout the sections, and are cut by 
syn-tectonic granitic dykes that yield ages of $c$. $394 \mathrm{Ma}$ (Johnston et al., 2010). Major element maps and compositions were analysed at the University of California, Santa Barbara electron microprobe facility; analysis procedures and representative compositions are documented in Table S1.

\section{Sample descriptions and mineral chemistry}

\section{Pelitic gneiss petrology}

Sample 6-14 is a banded stromatic migmatite gneiss with $\mathrm{cm}$-scale alternating Al-rich and Al-poor pelitic compositions interlayered with tonalitic leucosome. Al-poor layers are composed of $\mathrm{Grt}+\mathrm{Bt}+\mathrm{Pl}+$ $\mathrm{Qz} \pm \mathrm{Rt} \pm \mathrm{Ilm}$ (abbreviations after Whitney \& Evans, 2010), are rich in biotite and plagioclase, and are relatively garnet poor $(\sim 15 \%$ by volume; Fig. $3 b)$ compared to more aluminous layers. Garnet up to $2 \mathrm{~mm}$ in diameter is euhedral with abundant plagioclase and quartz inclusions. This garnet displays unzoned $\mathrm{Mg \#}(=\mathrm{Mg} /(\mathrm{Mg}+\mathrm{Fe}))$ with subtly variable $X_{\mathrm{Ca}}$ (from 0.08 to 0.09 ) across grain cores, and rims that display sharply increasing $X_{\mathrm{Mn}}$, and decreasing $X_{\mathrm{Ca}}$ and $\mathrm{Mg \#} \mathrm{(Fig.} \mathrm{3c).} \mathrm{Plagioclase} \mathrm{composition}$ ranges from $\mathrm{An}_{30-35}$ with more anorthitic compositions included within garnet. $\mathrm{Mg \#}$ in biotite ranges from 42 to 47 with more magnesian compositions in grain cores and in grains that are spatially isolated from garnet.

Al-rich layers are composed of $\mathrm{Grt}+\mathrm{Ky} / \mathrm{Sil}+$ $\mathrm{Bt}+\mathrm{Pl}+\mathrm{Qz} \pm \mathrm{Rt} \pm \mathrm{Ilm}$ and are differentiated from layers with lower $\mathrm{Al}$ by abundant garnet $(30-40 \%$ by volume) and the presence of kyanite porphyroblasts up to $1 \mathrm{~cm}$ long that have been partially replaced by sillimanite in strain shadows (Fig. 3a). Prismatic sillimanite is also abundant growing in the foliation with biotite, and as rare inclusions in garnet rims along with inclusions of lobate quartz and biotite. Garnet zoning in Al-rich layers displays unzoned $\mathrm{Mg \#}$ and $X_{\mathrm{Ca}}(0.06)$ across grain cores, with sharply increasing $X_{\mathrm{Mn}}$, and decreasing $\mathrm{Mg \#}$ and $X_{\mathrm{Ca}}$ in grain rims (Fig. 3c). Plagioclase composition in these layers is $\mathrm{An}_{28-32}$, while biotite displays similar $\mathrm{Mg \#} \mathrm{45-46} \mathrm{but}$ lower $\mathrm{TiO}_{2}$ than Al-poor layers. Ilmenite is found abundantly within the biotite-rich matrix in both Al-rich and Al-poor regions of the sample, whereas rutile is typically limited to inclusions within melanosome porphyroblasts. Monazite is abundant within the melanosome as inclusions within garnet, kyanite and biotite (Fig. 3b). The leucosome in sample 6-14 is tonalitic in composition and has been segregated into foliation-parallel bands that have sharp contacts with melanosome (Fig. 3a). Leucosome plagioclase displays antiperthitic lamellae with generally albitic although variable composition $\left(\mathrm{An}_{12-30}\right)$, and quartz ribbons display undulatory extinction and serrated grain boundaries characteristic of subgrain recrystallization.
Sample 6-2.1 is a weakly foliated pelitic diatexite migmatite gneiss consisting of $\mathrm{Grt}+\mathrm{Ky} / \mathrm{Sil}+\mathrm{Bt}+$ $\mathrm{Qz}+\mathrm{Pl}+\mathrm{Rt} \pm \mathrm{Ilm}$ melanosomes and tonalitic leucosomes (Fig. 2a). Spherical garnet up to $1 \mathrm{~cm}$ in diameter is complexly zoned with grain cores that display subtly decreasing $X_{\mathrm{Mn}}$ and $X_{\mathrm{Ca}}(<0.045)$ and gradually increasing then decreasing $\mathrm{Mg \#}$ towards grain mantles (Fig. 3d,g). Garnet mantles are best preserved adjacent to kyanite porphyroblasts, and are characterized by sharply increased $X_{\mathrm{Ca}}(>0.06)$, lower

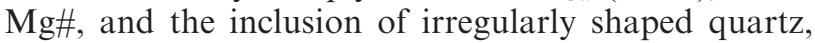
biotite and sillimanite needles adjacent to grain margins (Fig. 3e). Resorbed garnet rims, as identified by deeply embayed lobate grain boundaries with other melanosome phases or leucosome that have locally removed the entire high-Ca grain mantle, display rapidly increasing $X_{\mathrm{Mn}}$ and decreasing in $\mathrm{Mg \#}$ in the several hundred microns adjacent to grain boundaries. Kyanite is closely associated with garnet in the melanosome, and represents the dominant Al silicate phase in this sample with prismatic porphyroblasts that are up to $2 \mathrm{~cm}$ in length and that contain abundant rutile inclusions. Kyanite porphyroblasts are commonly deeply embayed along grain margins and cleavage planes, and are locally replaced by garnet with abundant sillimanite inclusions (Fig. 3e). Sillimanite is also found in plagioclase inclusions adjacent to garnet, and as unoriented blocky prisms and needles with $\mathrm{Bt} \pm \mathrm{Pl} \pm \mathrm{Qz}$ assemblages adjacent to embayed garnet porphyroblasts (Fig. 3e). Biotite occurs as rounded inclusions in garnet, and abundantly within the melanosome matrix as unoriented, coarse-grained aggregates that envelop garnet and kyanite porphyroblasts and stretch along the foliation. Biotite composition varies systematically from matrix biotite with $\mathrm{Mg \#} \mathrm{42-45}$ to more magnesian grains up to $\mathrm{Mg \#} 65$ included in garnet or adjacent to garnet rims. Ti content in biotite, also widely variable (from 2 to $4.4 \mathrm{wt} \% \mathrm{TiO}_{2}$ ), does not display any apparent systematic spatial patterns. Melanosome plagioclase occurs interstitially with quartz in biotite selvages, near embayed garnet porphyroblasts with sillimanite inclusions, and rarely as inclusions within garnet. Plagioclase composition $\left(\mathrm{An}_{28-30}\right.$ and $\left.\mathrm{Or}_{02}\right)$ is relatively unzoned in this sample and shows no systematic variation between the different grain morphologies, although K-rich lamellae up to $\mathrm{Or}_{25}$ are observed locally. Rutile inclusions are abundant within garnet and kyanite, while ilmenite is the dominant Ti-bearing phase associated with matrix biotite. Monazite is common within melanosome porphyroblasts (Fig. 3e). Leucosomal segregations comprise $20-40 \%$ of the rock by volume, display sharp contacts with melanosome, and are identified by their lighter colour and a distinct lack of garnet, kyanite and biotite. Leucosomes are broadly tonalitic in composition and are dominated by equant plagioclase grains $\left(\mathrm{An}_{30}, \mathrm{Or}_{02}\right)$ which display straight grain boundaries with interstitial quartz, and coarse quartz 

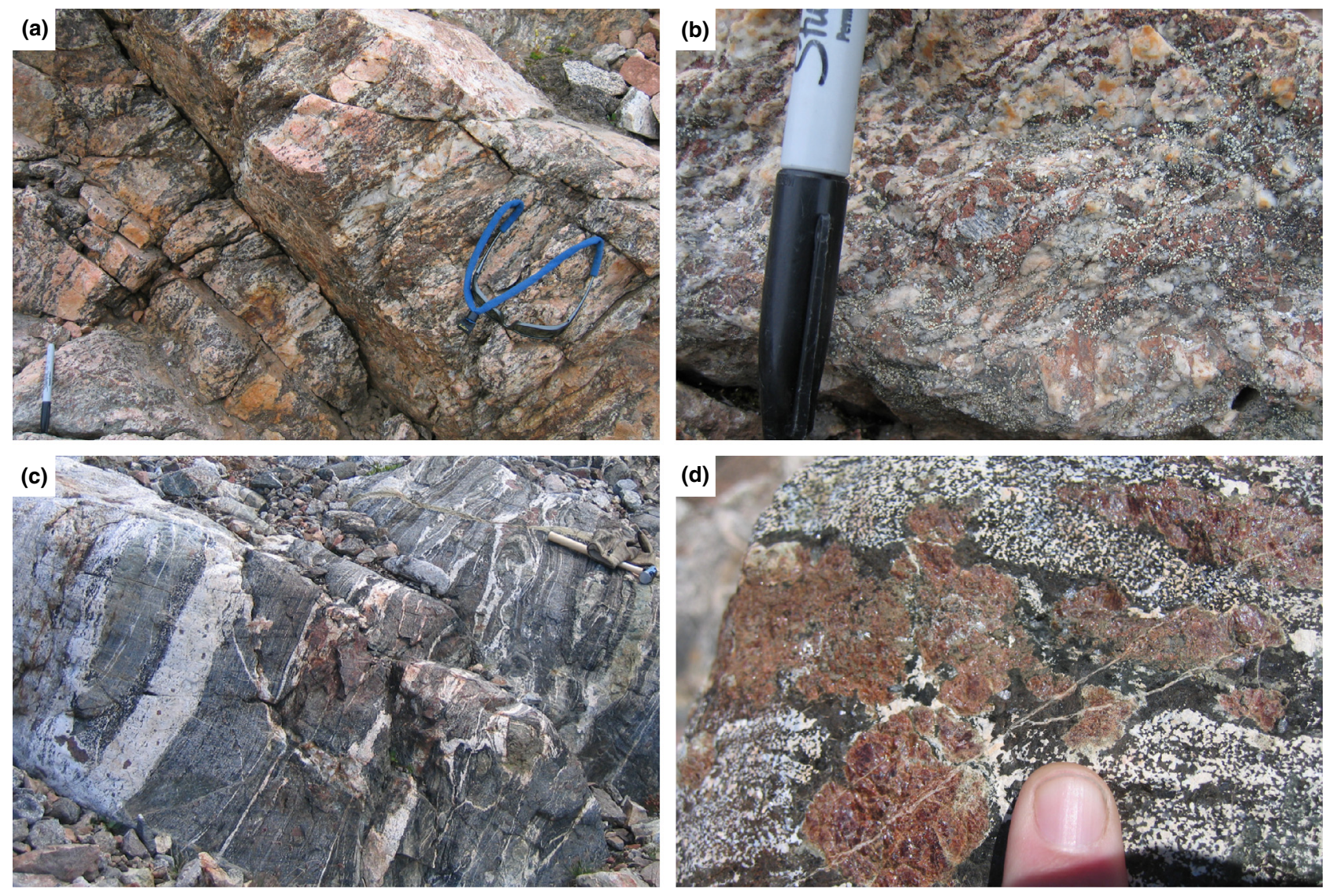

Fig. 2. Representative photographs illustrating outcrop and hand sample relationships in Jættedal complex migmatite gneisses. (a) Pelitic diatexite migmatite gneiss sample 6-2.1 with detail in (b). (c) Metamafic stromatic metatexite sample 6-1 with detail in $(\mathrm{d})$.

stringers with lobate grain boundaries and chessboard extinction. K-feldspar in the leucosome has been replaced by sericite and radiating aggregates of muscovite that cut across leucosome foliation (Fig. 3f), and is currently limited to K-rich lamellae in plagioclase.

\section{Mafic gneiss petrology}

Jættedal complex mafic interlayers are composed primarily of weakly foliated amphibolite. However, evidence for higher grade conditions is preserved in rare garnet amphibolites and several broad zones up to $50 \mathrm{~m}$ thick composed of a variety of garnet + amphibole \pm clinopyroxene migmatite gneiss (Fig. 2b). Orthopyroxene was not identified in the section. For this study, two stromatic metatexite migmatites, samples 6-1 and 6-7, composed of Grt $+\mathrm{Cpx}+\mathrm{Pl}$ $\pm \mathrm{Rt} \pm \mathrm{Ilm} \pm \mathrm{Amp} \pm \mathrm{Bt}$ melanosomes and plagioclase-rich leucosomes were selected for further investigation. Both samples are characterized by coarse, irregularly shaped, poikiloblastic garnet up to $5 \mathrm{~cm}$ in diameter that includes abundant clinopyroxene, rutile/ilmenite and apatite (Fig. 4a). Garnet major-element composition (Fig. 4b) is unzoned across grain cores $\left(\mathrm{Mg} \# 32-33, X_{\mathrm{Ca}} 0.18-0.21\right)$ with sharply decreasing $\mathrm{Mg} \#$ and increasing $X_{\mathrm{Ca}}$ and $X_{\mathrm{Mn}}$ in grain rims. Clinopyroxene occurs as inclusions within garnet, defining the melanosome foliation with plagioclase and amphibole, and abundantly within plagioclase-rich strain shadows surrounding garnet poikiloblasts. Clinopyroxene is $\mathrm{Ca}$-rich augite with low $\mathrm{Na}(<0.04 \mathrm{pfu})$ and variable $\mathrm{Mg} \#$ depending on textural setting: higher $\mathrm{Mg \#}$ grains are included within and adjacent to garnet, whereas grains isolated

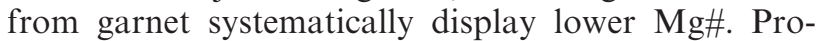
grade amphibole ranges in composition from pargasite to magnesio-hornblende with $\mathrm{Mg} \#$ of 55-60 and $\mathrm{TiO}_{2}$ of $0.95-1.75 \mathrm{wt} \%$. Amphibole occurs throughout the matrix in equilibrium with clinopyroxene and plagioclase in sample 6-7, and limited amphibolite selvages without garnet or clinopyroxene in sample 6-1. Plagioclase lacks twinning and displays albitic compositions $<\mathrm{An}_{10}$ in sample 6-7, although several grains associated with clinopyroxene in sample 6-1 display polysynthetic twinning and preserve calcic cores with $\mathrm{An}_{27-31}$. Both quartz and orthopyroxene are conspicuously absent from the melanosome, while 


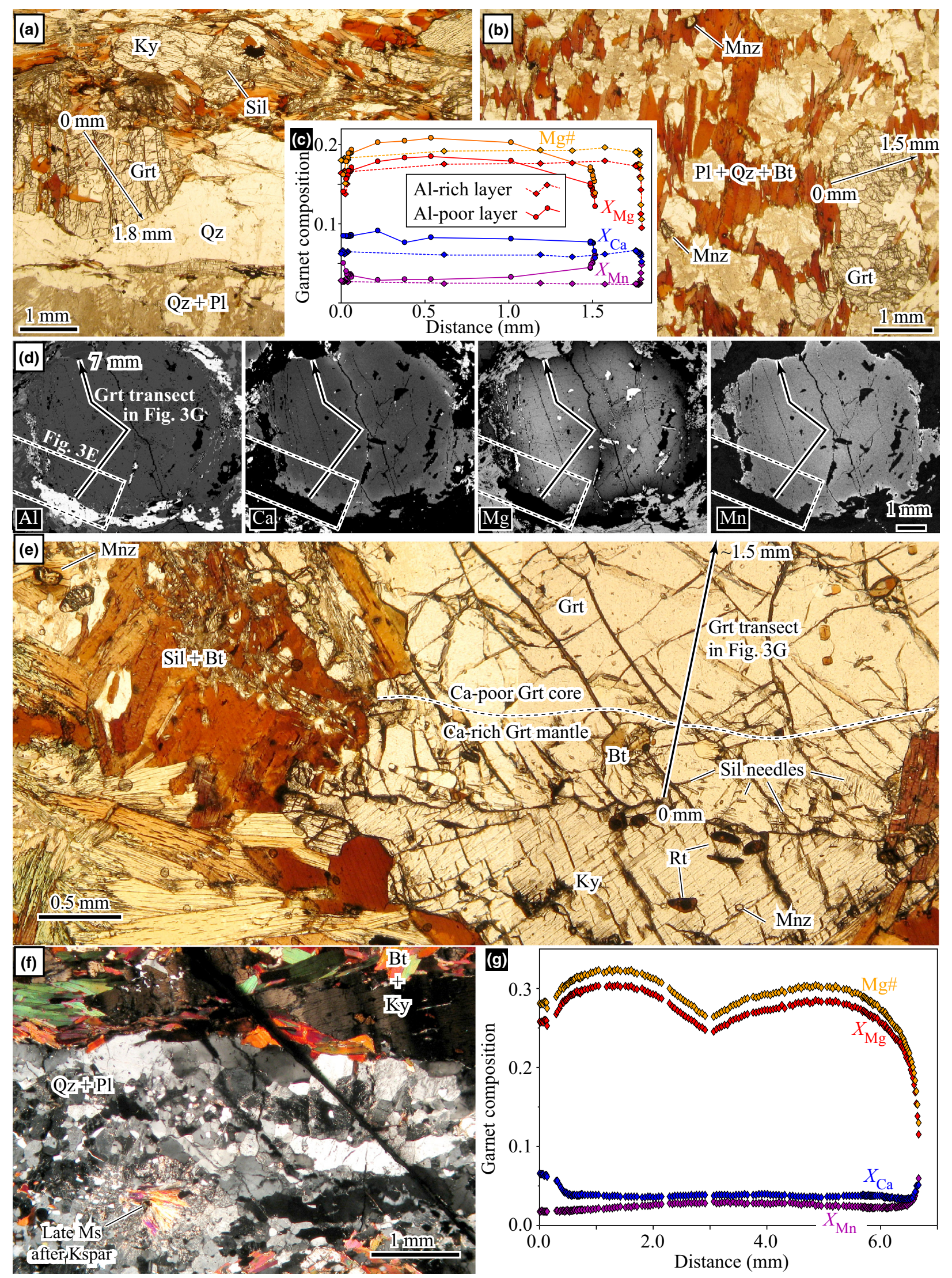


Fig. 3. Petrography and major-element chemistry of pelitic gneisses sample 6-14 (a-c) and sample 6-2.1 (d-g). Photomicrographs illustrating mineralogy and textures characteristic of Al-rich (a) and Al-poor (b) layers in sample 6-14. Solid black lines with distance labels $(\mathrm{mm})$ indicate the location of electron microprobe spot analysis transects documenting major-element garnet composition plotted in (c); transect distance increases from left to right in both samples. (d) Major element map from sample 6-2.1 illustrating garnet porphyroblast zoning and textural relationships with adjacent phases. Note the Ca-rich mantle is best preserved adjacent to kyanite porphyroblasts. (e) Photomicrograph detail of the area delineated by the dotted line in (d). Note the biotite and sillimanite needles included within the Ca-rich garnet mantle, the irregular shaped contact between garnet and kyanite, and unoriented needles of sillimanite growing intimately with biotite in the garnet strain shadow. (f) Cross-polarized photomicrograph illustrating the textural relationship between the melanosome and leucosome in sample 6-2.1. Note the radiating aggregate of muscovite and sericite replacing K-feldspar in the leucosome. (g) Garnet major-element chemistry from the electron microprobe spot analysis transect illustrated by the solid lines distance labels in (d) and (f); transect distance increases from the bottom to the top of the garnet in both figures. Note that Ca-rich mantles adjacent to kyanite preserve higher $\mathrm{Mg} \#$ and lower $X_{\mathrm{Mn}}$ than resorbed rims adjacent to biotite.

titanite is observed as an abundant accessory phase frequently overgrowing rutile and ilmenite. Additional accessory phases include abundant apatite in both samples, whereas zircon is abundant in sample 6-1 and rare in sample 6-7.

Leucosomes in the mafic migmatites appear as isolated stroma and boudin necks in neosome, throughout the melanosome in low-strain layers, and as concordant dykes up to $20 \mathrm{~cm}$ thick with entrained garnet and clinopyroxene porphyroclasts. Leucosome borders variably display sharp contacts with unaltered melanosome, or more diffuse contacts with dark, amphibolerich selvedges. In areas dominated by melanosome, leucosomal segregations are predominantly plagioclase with accessory titanite and little to no quartz.

Retrograde textures in the mafic gneiss include widespread albitization of plagioclase, and amphibole overgrowths on pyroxene. When compared with prograde amphibole, retrograde amphibole displays similar pargasitic to magnesio-hornblende compositions, but with higher $\mathrm{Mg \#} \mathrm{(54-71)} \mathrm{and} \mathrm{lower} \mathrm{TiO}_{2}(0.72$ $1.45 \mathrm{wt} \%)$. Chlorite replaced biotite along fractures in garnet, and also occurs as late, cross-cutting grains distributed throughout the melanosome matrix. Late calcite veins and pumpellyite occur in both samples.

\section{Reaction history and thermobarometry}

In this section, petrological observations are used in conjunction with published petrogenetic grids, experimental data and thermobarometry to interpret the $P-T$ evolution of the Jættedal complex. Relevant phase equilibria (Fig. 5) were calculated using THERMOCALC v.3.33 (Powell \& Holland, 1988).

\section{Pelitic gneiss petrogenesis}

Mineral textures in samples with pelitic composition are consistent with a reaction history characterized by prograde melting associated with muscovite and biotite melting reactions (Fig. 5a). Garnet cores are unzoned in sample 6-14, but complexly zoned garnet in sample 6-2.1 with subtly decreasing $X_{\mathrm{Mn}}, X_{\mathrm{Ca}}$, and increasing $\mathrm{Mg} \#$ across cores is suggestive of an early prograde history with a $P-T$ trajectory sufficiently shallow to cross moderately sloped isopleths of net transfer reactions between garnet and plagioclase. The widespread development of leucocratic segregations and the lack of prograde muscovite in both samples indicate melting through either water-present or waterabsent muscovite breakdown reactions of the form:

$$
\mathrm{Ms}+\mathrm{Pl}+\mathrm{Qz}+\mathrm{H}_{2} \mathrm{O}=\mathrm{Als}+\mathrm{L}
$$

or

$$
\mathrm{Ms}+\mathrm{Pl}+\mathrm{Qz}=\mathrm{Als}+\mathrm{Kfs}+\mathrm{L}
$$

The K-poor tonalitic composition of the pelitic leucosomes is consistent with water-fluxed melting (Patiño Douce \& Harris, 1998), although dehydration melting of muscovite and subsequent fractionation of the K-rich components from the melt cannot be ruled out without more detailed sampling and geochemistry. Both of these melting reactions form Al silicate regardless of water availability, and the presence of abundant porphyroblastic kyanite suggests that initial melting in these rocks occurred in the kyanite stability field at pressures $>7 \mathrm{kbar}$ as constrained by water-present melting reaction (1a) and $\mathrm{Al}$ silicate phase relations.

The growth of high $X_{\mathrm{Ca}}$ garnet mantles in diatexite migmatite sample 6-2.1 indicates renewed growth of garnet in equilibrium with more calcic plagioclase following muscovite breakdown melting (e.g. Spear \& Kohn, 1996), and supports additional melting via the continuous reaction for biotite dehydration:

$$
\mathrm{Bt}+\mathrm{Als}+\mathrm{Pl}+\mathrm{Qz}=\mathrm{Grt}+\mathrm{Kfs}+\mathrm{L}
$$

Irregularly shaped garnet lobes that penetrate into embayed kyanite porphyroblasts (Fig. 3e) are interpreted as new garnet growth at the expense of kyanite and provide petrographic support for this reaction. The lack of $\mathrm{K}$-feldspar in the melanosome suggests that $\mathrm{K}_{2} \mathrm{O}$ was dissolved into the melt (Spear et al., 1999) as this reaction went forward. The inclusion of biotite and sillimanite needles in high $X_{\mathrm{Ca}}$ garnet mantles adjacent to embayed kyanite (Fig. 3e) likely represent reactants for reaction (2) that were not fully consumed (e.g. Whitehouse \& Platt, 2003), and suggest that biotite dehydration melting proceeded within the sillimanite stability field. Lower $\mathrm{Mg \#}$ in garnet mantles with respect to cores opens the possibility that initial melting reactions (1a) or (1b) were preceded by decompression as suggested by 

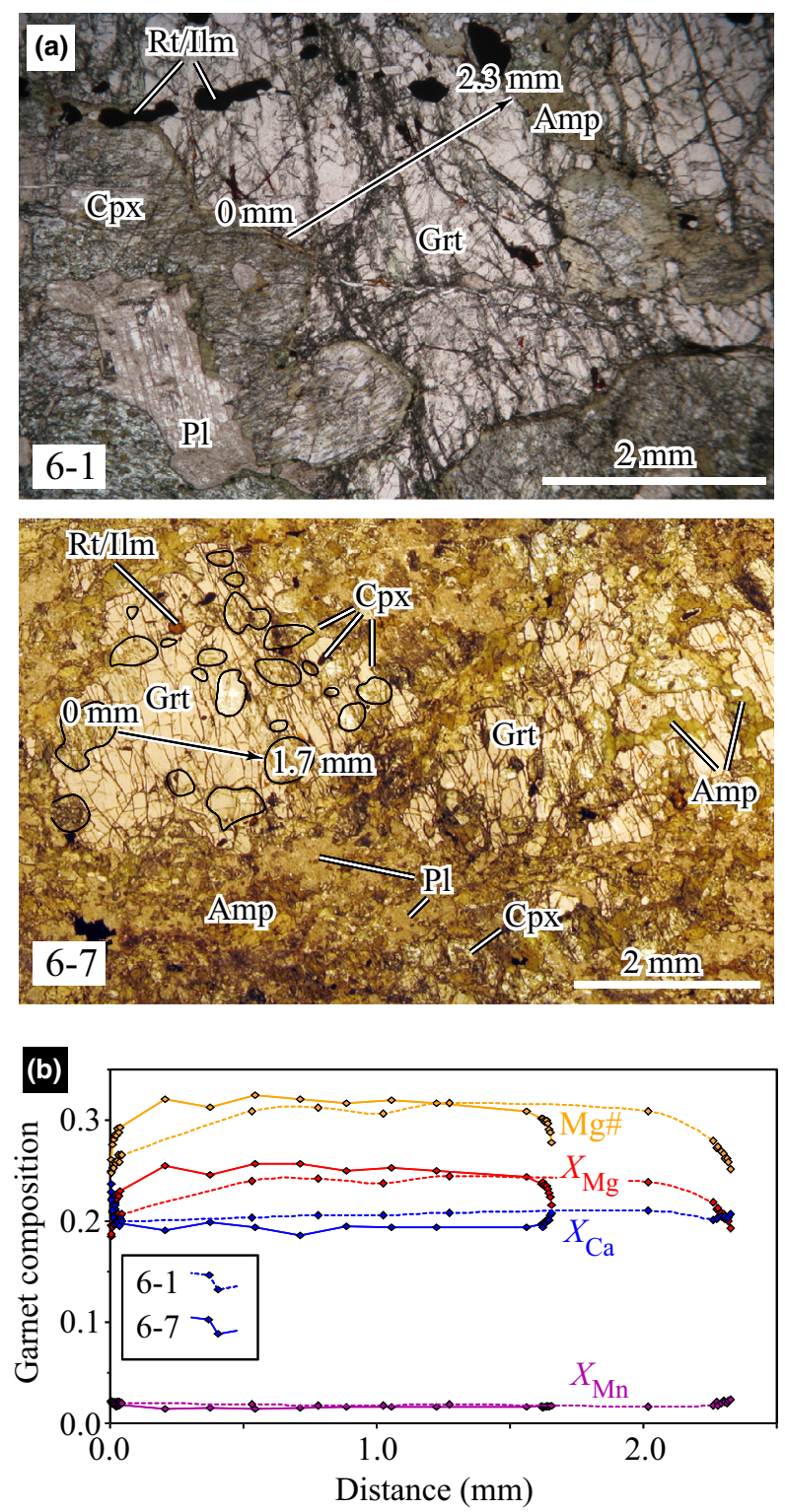

Fig. 4. (a) Photomicrographs illustrating the textural relationships of the peak phase assemblage

Grt $+\mathrm{Cpx}+\mathrm{Pl} \pm \mathrm{Rt} \pm \mathrm{Ilm} \pm$ Amp in metamafic samples 6-1 and 6-7. (b) Electron microprobe major element data illustrating unzoned garnet cores from the transects illustrated by black lines with arrows in (a); transect distance increases from left to right in both samples.

down-pressure decreases in garnet $\mathrm{Mg} \#$ predicted by the reaction:

$$
\mathrm{Grt}+\mathrm{Ms}=\mathrm{Bt}+\mathrm{Als}
$$

Regardless of this potential early decrease in pressure, increasing $\mathrm{Mg} \#$ in high $X_{\mathrm{Ca}}$ garnet mantles, and steep isopleths for continuous biotite dehydration melting (Spear et al., 1999), indicate that garnet growth and melting via reaction (2) was a prograde reaction caused by progressive heating of the Jættedal complex rather than a result of retrograde decompression. The presence of residual biotite limits peak metamorphic temperatures to less than 850$870{ }^{\circ} \mathrm{C}$, the temperature at which melting experiments on typical pelites indicate that biotite is fully consumed by reaction (2) (Vielzeuf \& Holloway, 1988). Similarly, the lack of orthopyroxene defines an upper temperature limit of $900{ }^{\circ} \mathrm{C}$ at $10 \mathrm{kbar}$ (Carrington $\&$ Harley, 1995) through the univariant reaction:

$$
\mathrm{Bt}+\mathrm{Grt}+\mathrm{Kfs}+\mathrm{Qz}=\mathrm{Opx}+\mathrm{Sil}+\mathrm{L}
$$

Subsequent to peak metamorphism, finely intergrown sillimanite and biotite in sample 6-2.1 (Fig. 3e) indicate the reversal of reaction (2) during early retrograde cooling. The lack of cordierite in the samples constrains the retrograde path to pressures above the reaction

$$
\mathrm{Bt}+\mathrm{Sil}+\mathrm{Qz}=\mathrm{Grt}+\mathrm{Crd}+\mathrm{Kfs}+\mathrm{L}
$$

This retrograde path is consistent with moderate exhumation rates rather than rapid exhumation and isothermal decompression. Finally, the development of late muscovite after K-feldspar in the leucosomes (Fig. 3f) implies pressures above the invariant point at the intersection of the wet solidus with muscovite dehydration $\left(\sim 4 \mathrm{kbar}\right.$ at $\left.650{ }^{\circ} \mathrm{C}\right)$ during final crystallization of the melt (e.g. Spear et al., 1999).

Additional constraints on the conditions of peak metamorphism in the Jættedal complex pelites can be placed using mineral compositions to calculate the positions of well-calibrated reaction equilibria (Fig. 5a). Determining peak metamorphic temperatures using garnet-biotite thermometry (Ferry \& Spear, 1978) is hampered in high-grade metamorphic rocks by retrograde reactions encountered along the cooling path (e.g. Spear \& Parrish, 1996), and we interpret geothermometry results cautiously. Of the investigated samples, Al-poor layers of sample 6-14 are best suited for garnet-biotite exchange thermometry because the abundance of biotite and relative paucity of garnet effectively buffers biotite compositions against volumetrically insignificant retrograde reactions with garnet. Pairing garnet mantles displaying unzoned $\mathrm{Mg} \#$ and low $X_{\mathrm{Ca}}$ with matrix biotite cores found far from garnet yields temperatures of 854$883{ }^{\circ} \mathrm{C}$ at $8-10 \mathrm{kbar}$. Still, sharply decreasing $X_{\mathrm{Ca}}$ observed in resorbed garnet rims, and matrix biotite with rimward decreasing $\mathrm{Mg} \#$, suggests equilibration of matrix biotite through retrograde net transfer reactions (Hoisch, 1990, 1991) occurred during subtle decompression at or near peak temperature. As such, garnet-biotite pairs from sample 6-14 are interpreted to represent maximum estimates for peak metamorphic temperatures.

Net transfer reactions including Grt-Bt-Pl-Qz (GBPQ, Hoisch, 1991) and Grt-Pl-Qz-Als (GASP, Koziol \& Newton, 1988) can be used to place constraints on metamorphic pressures. Here, GBPQ was applied to Al-poor layers in sample 6-14, and GASP 

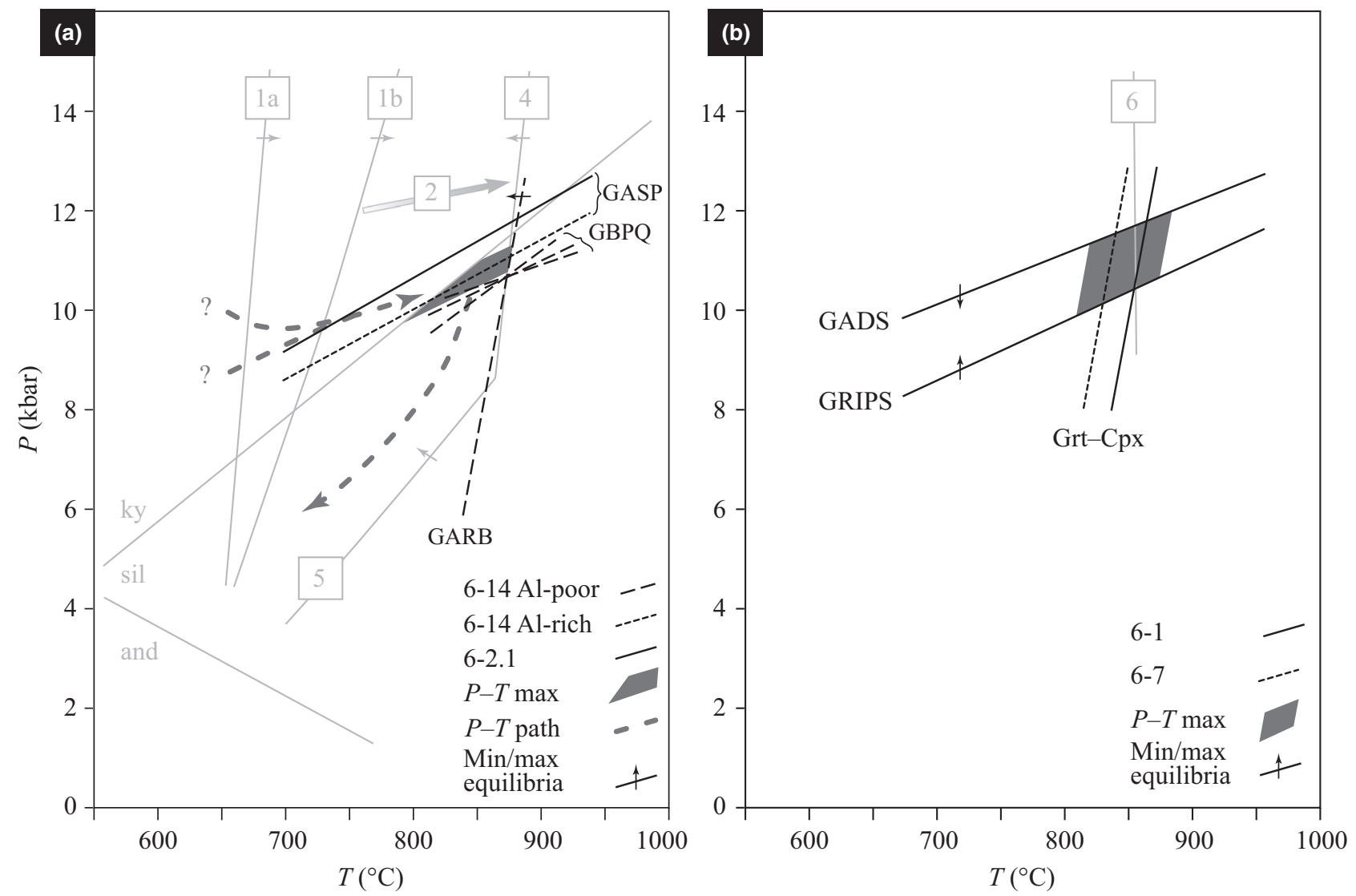

Fig. 5. Thermobarometric equilibria from investigated samples illustrating interpreted maximum $P-T$ conditions from (a) pelitic migmatites and (b) metamafic migmatites. Numbered grey lines are relevant equilibria from the literature discussed in the text. Reactions (1a) or (1b), (2), (4) and (5) are from the pelitic NaKFMASH grid of Spear et al. (1999); the gradational arrow indicating reaction (2) is roughly perpendicular to isopleths of $\mathrm{Mg \#}$ in garnet through the temperature-space in which this continuous reaction proceeds. Reaction (6) is from Winther \& Newton (1991).

was applied to Al-rich layers in samples 6-14 and 62.1. Equilibria were calculated by pairing garnet mantles with melanosome plagioclase, and with matrix biotite in the case of Al-poor layers of 6-14; quartz and Al silicate activity was assumed to be at unity. At $850{ }^{\circ} \mathrm{C}, \mathrm{GBPQ}$ and GASP yield similar pressures of 10.4 and $10.7-11.4$ kbar respectively (Fig. 5a). The slightly lower pressure calculated with GPBQ may be associated with the formation of $\mathrm{Fe}$ rich biotite during early retrogression in Al-poor 614 , whereas pressure greater than the stability field of sillimanite calculated with GASP for sample 6-2.1 suggests that plagioclase analysed in this sample may not have been in equilibrium with garnet. We thus consider GASP equilibria from Al-rich layers of 6-14 the most reliable thermobarometer, and when constrained by the stability field of sillimanite and biotite-out melting reactions, it indicates pressures of 10-10.7 kbar at peak metamorphic temperatures.

\section{Mafic gneiss petrogenesis}

The Jættedal complex mafic migmatite gneisses show characteristics of prograde amphibole breakdown melting at amphibolite to granulite facies temperatures and intermediate to high pressures. Grt $+\mathrm{Cpx}+\mathrm{Pl}$ assemblages together with tonalitic melts in mafic rocks can be attributed to high- $P$, garnet-stable amphibole dehydration (e.g. Pattison, 2003):

$$
\mathrm{Amp}+\mathrm{Pl} \pm \mathrm{Qtz}=\mathrm{Grt}+\mathrm{Cpx}+\mathrm{L}
$$

Melting experiments constrain garnet stability in anatectic mafic rocks to pressures $>\sim 7 \mathrm{kbar}$, and amphibole dehydration and anatexis at these higher pressures can initiate at amphibolite facies temperatures as low as the wet solidus (Wolf \& Wyllie, 1994). However, significant generation of augitic clinopyroxene with poikiloblastic garnet does not occur in these melting experiments until higher temperatures (Wolf \& Wyllie, 1993). Most experimental studies place reaction (6) at temperatures of $800-900{ }^{\circ} \mathrm{C}$ with near-vertical $\mathrm{d} P / \mathrm{d} T$ (Winther \& Newton, 1991; Rushmer, 1993; López \& Castro, 2001) and are consistent with progressively increasing temperatures during melting of the Jættedal samples. Grt $+\mathrm{Cpx}+\mathrm{Pl}$ assemblages have been observed in natural samples deformed at conditions as low as amphibolite facies, although higher $\mathrm{TiO}_{2}$ in amphibole, lower $X_{\mathrm{Ca}}$ in garnet and the 
presence of abundant melt in the Jættedal complex mafic gneisses are more similar to natural rocks metamorphosed at upper amphibolite to granulite facies temperatures (Pattison, 2003, and references therein). The absence of quartz in the melanosome, presumably due to its consumption through reaction (6) during prograde melting, likely inhibited the creation of orthopyroxene during the down-pressure reaction:

$$
\mathrm{Grt}+\mathrm{Cpx}+\mathrm{Qtz}=\mathrm{Opx}+\mathrm{Pl}
$$

As such, the observed phase assemblage does not place any significant constraints on the retrograde $P-T$ evolution of the Jættedal complex.

Phase equilibria and thermobarometry further constrain the metamorphic conditions of the mafic gneisses. Pairing homogenously high $\mathrm{Mg} \#$ garnet cores with low $\mathrm{Mg \#}$ matrix clinopyroxene far from garnet to minimize the effects of retrograde $\mathrm{Fe}-\mathrm{Mg}$ exchange, Grt-Cpx thermometry (Ellis \& Green, 1979) yields temperatures of $852-829^{\circ} \mathrm{C}$ at $10 \mathrm{kbar}$. These temperatures are consistent with granulite facies conditions during amphibole dehydration melting. Applicable barometers in these rocks include the net transfer reactions Grt-Pl-Cpx-Qz (GADS, Newton \& Perkins, 1982) and Grt-Pl-Rt-Ilm-Qz (GRIPS, Bohlen \& Liotta, 1986). Equilibria were determined by pairing garnet cores, matrix clinopyroxene and plagioclase compositions with assumed activities of 1 for quartz, ilmenite and rutile. The scarcity of quartz in these samples indicates the likelihood of quartz activity $<1$, and requires that GADS equilibria represent pressure maxima (e.g. Hartel \& Pattison, 1996). Conversely, subunity quartz and ilmenite activities require that GRIPS equilibria represent pressure minima. Pervasive alteration of plagioclase to albite prohibited the use of these barometers in sample 6-7. However, high An cores from plagioclase inclusions in clinopyroxene in sample 6-1 bracket peak metamorphic pressures between $\sim 12$ and $10 \mathrm{kbar}$ at $850^{\circ} \mathrm{C}$ as indicated by the GADS maximum and GRIPS minimum respectively.

\section{U-Pb ZIRCON GEOCHRONOLOGY AND REE GEOCHEMISTRY}

$\mathrm{U}-\mathrm{Pb}$ zircon geochronology and geochemistry were performed on the pelitic and mafic migmatite gneisses to place constraints on the timing of metamorphism and partial melting in the Jættedal complex. This work expands on previous zircon geochronology from the Jættedal complex pelitic gneisses (Johnston et al., 2010) by adding trace element geochemistry to $\mathrm{U}-\mathrm{Pb}$ geochronology, and by investigating zircon from a wider variety of protolith compositions. Zircon from each of the samples described above was separated using standard mineral separation techniques, mounted in 1" epoxy plugs, polished approximately one-third of the way through the mounted grains, and imaged using CL to identify potential chemical zoning associated with inherited grain cores and metamorphic rims. CL images were used to guide placement of $20 \mu \mathrm{m}$ spots for simultaneous analysis of $\mathrm{U}-\mathrm{Pb}$ isotopes and REE concentrations following Kylander-Clark et al. (2013) using the laser-ablation split-stream ICP technique at the University of California, Santa Barbara. Isotope and trace element data were calibrated using reference zircon 91500 (1065 Ma, Wiedenbeck et al., 1995); 30 analyses of secondary standard GJ1 (601.7 \pm 1.3 Ma, D. Condon, pers. comm.) over four analytical sessions yield a ${ }^{206} \mathrm{~Pb} /{ }^{238} \mathrm{U}$ weighted average age of $599.7 \pm 6.2 \mathrm{Ma}$. Reported $\mathrm{U}-\mathrm{Pb}$ ratios and ages are not corrected for common $\mathrm{Pb}$, and errors on individual analyses are analytical only. Weighted average ages for analyses that represent a single population are reported with analytical errors added in quadrature to $1 \%$ systematic error inherent in the analysis procedure. Concentrations for Ce, Dy and Lu normalized to chondrite are used to track light, middle and heavy REE values respectively. Complete analytical results including zircon $\mathrm{CL}$ images, $\mathrm{U}-\mathrm{Pb}$ isotopes and REE concentrations for all zircon analyses are provided in Figs S1-S4 and Tables S2 and S3.

\section{Zircon morphology and analytical results}

Pelitic gneiss zircon

Abundant zircon separated from pelitic gneiss samples 6-2.1 and 6-14 is typically $50-100 \mu \mathrm{m}$ in diameter, with dominantly colourless, rounded grains in sample 6-2.1, and a variety of zircon morphologies, from rounded to prismatic and pale yellow to colourless in sample 6-14. In CL, both samples display a variety of dark-light, oscillatory zoned cores, that are overgrown by rims up to $50 \mu \mathrm{m}$ thick typically characterized by a dark inner annulus enveloped by bright sector- or planar-zoned outer rims (Fig 6). The ICP analyses primarily targeted zircon rims, but several grain cores and discordant analyses from both samples are consistent with inherited Archean and Proterozoic detrital populations. These analyses from grain cores are characterized by positive heavy rare earth element (HREE) slopes, high $\mathrm{Th} / \mathrm{U}(>0.1)$ and variable Ce concentrations of $2-30 \mathrm{ppm}$ with higher values that loosely correlate with increasing ${ }^{206} \mathrm{~Pb} /{ }^{207} \mathrm{~Pb}$ age (Fig. 7).

In contrast to zircon cores, analyses from the rims spread along concordia with ages of 460-420 Ma. These rims typically display negative $\mathrm{Eu}$ anomalies and relatively depressed HREE and Ce concentrations, although they still show considerable geochemical variation (Fig. 7). Concordant rims in sample 614 display consistently low $\mathrm{Th} / \mathrm{U}$ ratios $(<0.05$ in 25 of 28 analyses), low light rare earth element (LREE) concentrations $\left(\mathrm{Ce}_{n}<2\right.$ in 25 of 28 analyses) and low HREE concentrations. Chondrite-normalized REE plots yield negative, flat and positive HREE slopes 


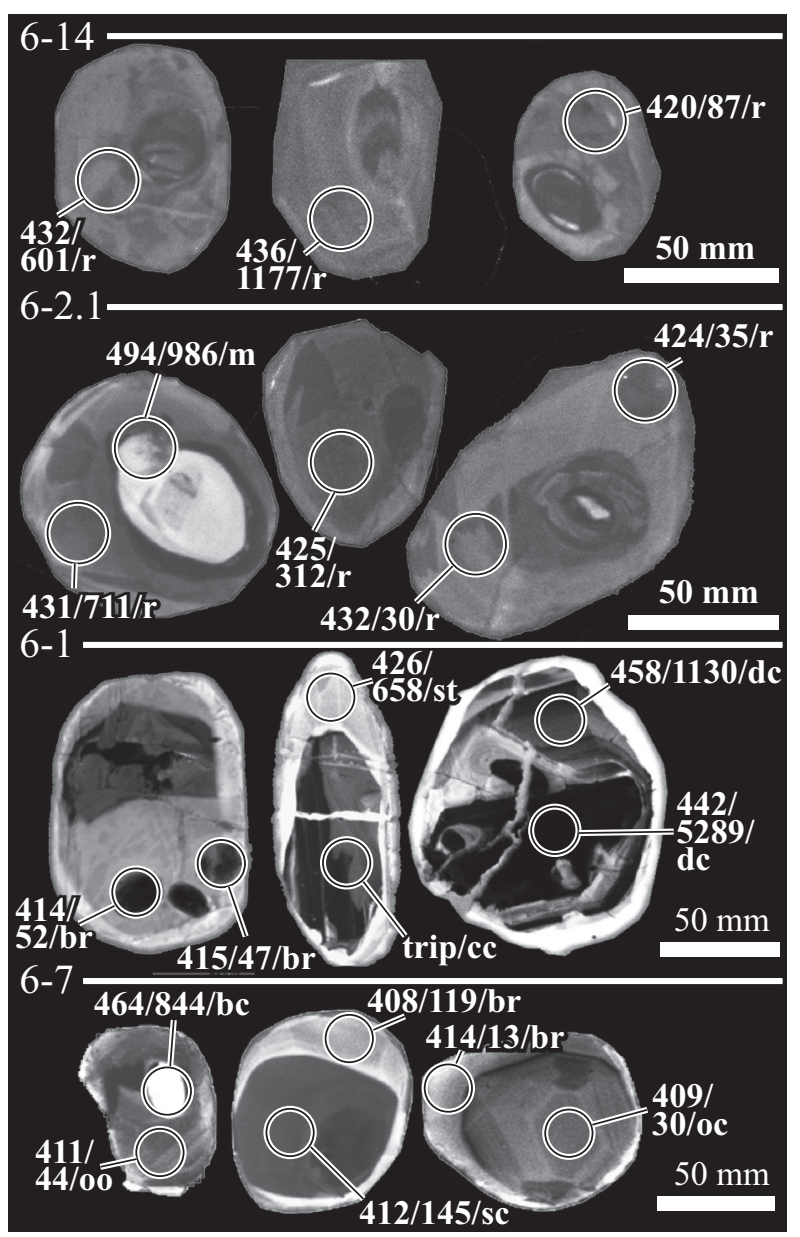

Fig. 6. Representative zircon CL images with LASS ICPMS spot locations. Analysis labels indicate age $(\mathrm{Ma}) / \mathrm{Lu}_{n} / \mathrm{CL}$ image character. CL images characteristics described in the text are abbreviated as follows: bc, bright core; br, bright rim; r, rim; cc, convoluted core; dc, dark core; m, mixed core and rim; oc, oscillatory core; oo, oscillatory overgrowth; sc, sector-zoned core; st, sector-zoned prism tip.

with $\mathrm{Lu}_{n}$ concentrations that range from 68 to 1382 . The ${ }^{206} \mathrm{~Pb} /{ }^{238} \mathrm{U}$ ages from all concordant rim analyses define a sharp age probability maxima at $440 \mathrm{Ma}$ flanked by a subsidiary peak at $450 \mathrm{Ma}$ and long tails that span ages from 461 to $420 \mathrm{Ma}$.

Concordant rim analyses in sample 6-2.1 display variable LREE and HREE concentrations such that three geochemically distinct populations can be defined: low HREE analyses with $\mathrm{Lu}_{n}<40$, moderate HREE analyses with $\mathrm{Lu}_{n}$ 50-300 and two analyses with high HREE analyses with $\mathrm{Lu}_{n}>700$ (Fig. 7). In low and moderate HREE populations, LREE are inversely correlated with HREE concentration as illustrated by average $\mathrm{Ce}_{n}$ values of $3.6 \pm 1.1$ in low HREE analyses and $0.8 \pm 0.5$ in moderate HREE analyses. The $\mathrm{U}$ and Th concentrations also vary systematically in these analyses with high $\mathrm{Th} / \mathrm{U}$ ratios $>0.05$ in low HREE analyses that are distinct from
$\mathrm{Th} / \mathrm{U}$ ratios $<0.05$ in moderate HREE analyses. High HREE analyses are comparable to the moderate HREE population with lower Ce concentrations and lower Th/U ratios, although HREE slopes are strongly positive. Despite this considerable variation in geochemistry, no apparent correlation with CL morphology was observed, and all three geochemical populations are developed in sector-zoned outer rims (Fig. 6). When all concordant rim analyses are considered together, ${ }^{206} \mathrm{~Pb} /{ }^{238} \mathrm{U}$ ages span from 444 to $422 \mathrm{Ma}$ and yield a probability maximum at $431 \mathrm{Ma}$. When considered as discrete geochemical populations, analyses from low HREE zircon are characterized by younger ages with a broad probability function maxima at $c$. $430 \mathrm{Ma}$. In contrast, moderate HREE zircon is skewed towards older ages that define a bimodal age probability function with maxima at c. 440 and $430 \mathrm{Ma}$. The two high HREE analyses yield ages of 431 and $430 \mathrm{Ma}$.

\section{Mafic gneiss zircon}

Zircon separated from mafic gneiss also exhibits complex chemical zoning, although concordant $\mathrm{U}-\mathrm{Pb}$ analyses are limited to ages from 470 to $405 \mathrm{Ma}$. Sample 6-1 contains abundant colourless prismatic to equant zircon $100-200 \mu \mathrm{m}$ in length. In CL, these grains display cores with complex spatial relationships between domains that are alternately characterized by dark oscillatory to homogenous zoning and lighter convoluted zones (Fig. 6). Zircon rims display bright, well-developed sector zoning at prism tips in two grains, although grain rims are more commonly characterized by bright domains up to $60 \mu \mathrm{m}$ thick that transgress grain cores along contacts and fractures, and that brighten abruptly towards grain edges. These different grain morphologies are associated with systematic geochemical trends (Fig. 8). In general, dark cores are associated with older ages from 471 to $444 \mathrm{Ma}$, high $\mathrm{Th} / \mathrm{U}$, high $\mathrm{U}$, and relatively enriched light, middle and heavy REE concentrations that form positive slopes on chondritenormalized REE plots. Analyses from convoluted core domains span concordia space yield old to younger ages of 473-429 Ma with lower Th/U, lower U, depleted LREE and MREEs, and only subtly depleted HREE such that chondrite-normalized plots are steeply positive. Two analyses with sector-zoned prism tips yield ages of c. $425 \mathrm{Ma}$, and display trace element geochemistry similar to convoluted cores. Analyses from bright rims are younger still from 438 to $414 \mathrm{Ma}$ with decreased $\mathrm{Th} / \mathrm{U}$, lower $\mathrm{U}$, depleted LREE and MREEs, and subtly to extremely depleted HREE such that the most depleted analyses display flat HREE slopes. All grain morphologies display negative Eu anomalies.

Zircon separated from mafic gneiss sample 6-7 forms equant to prismatic colourless grains 50 $150 \mu \mathrm{m}$ in length. CL images reveal two dominant 

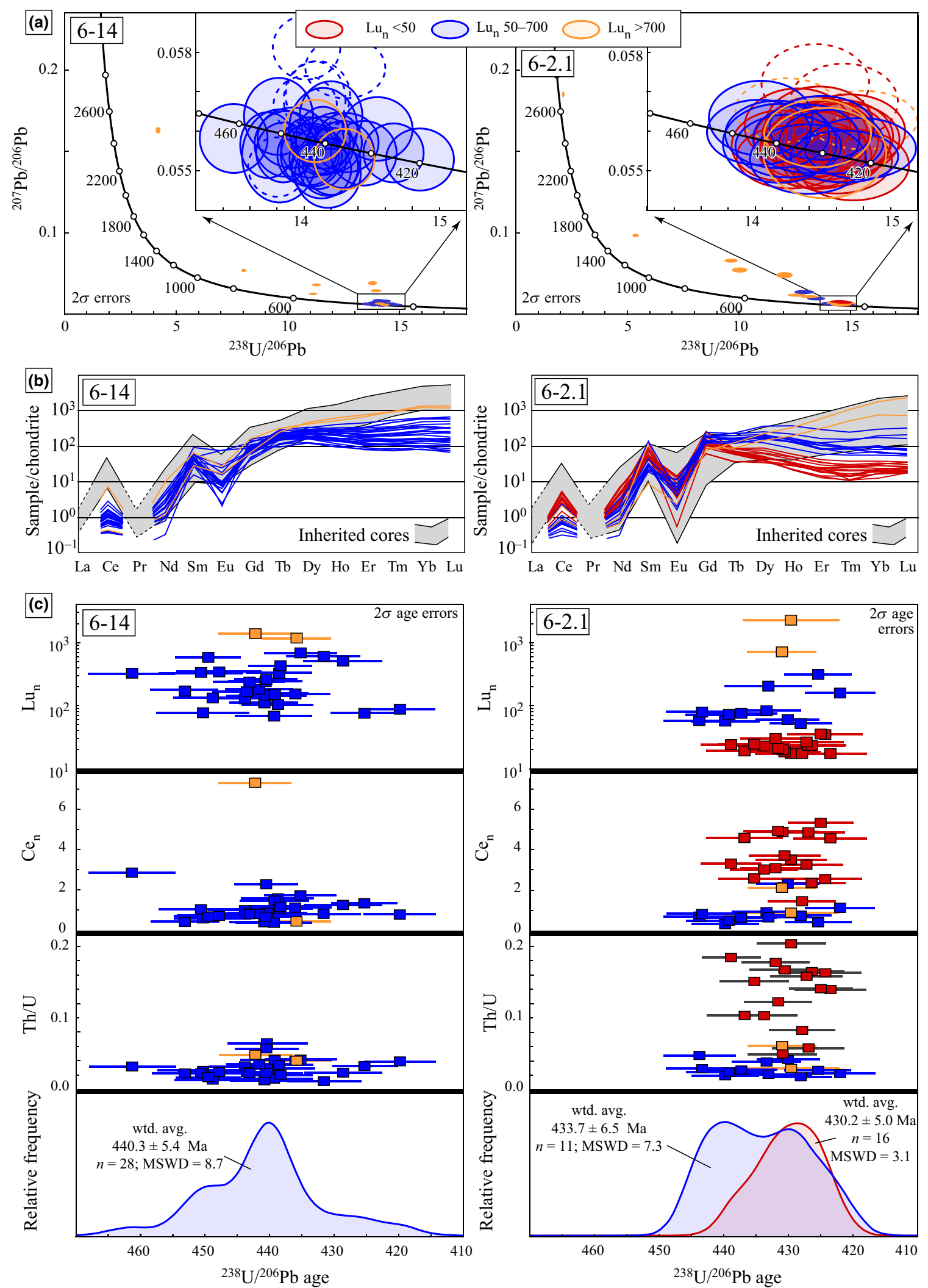

Fig. 7. LASS ICPMS data from pelitic migmatite zircon illustrating (a) U-Pb isotopic data, (b) chondrite-normalized REE plots and (c) trace element ratios with age probability density plots for concordant analyses. Error ellipses in (a) indicate $2 \sigma$ internal errors. Colours in (b) and (c) follow the legend in (a). 

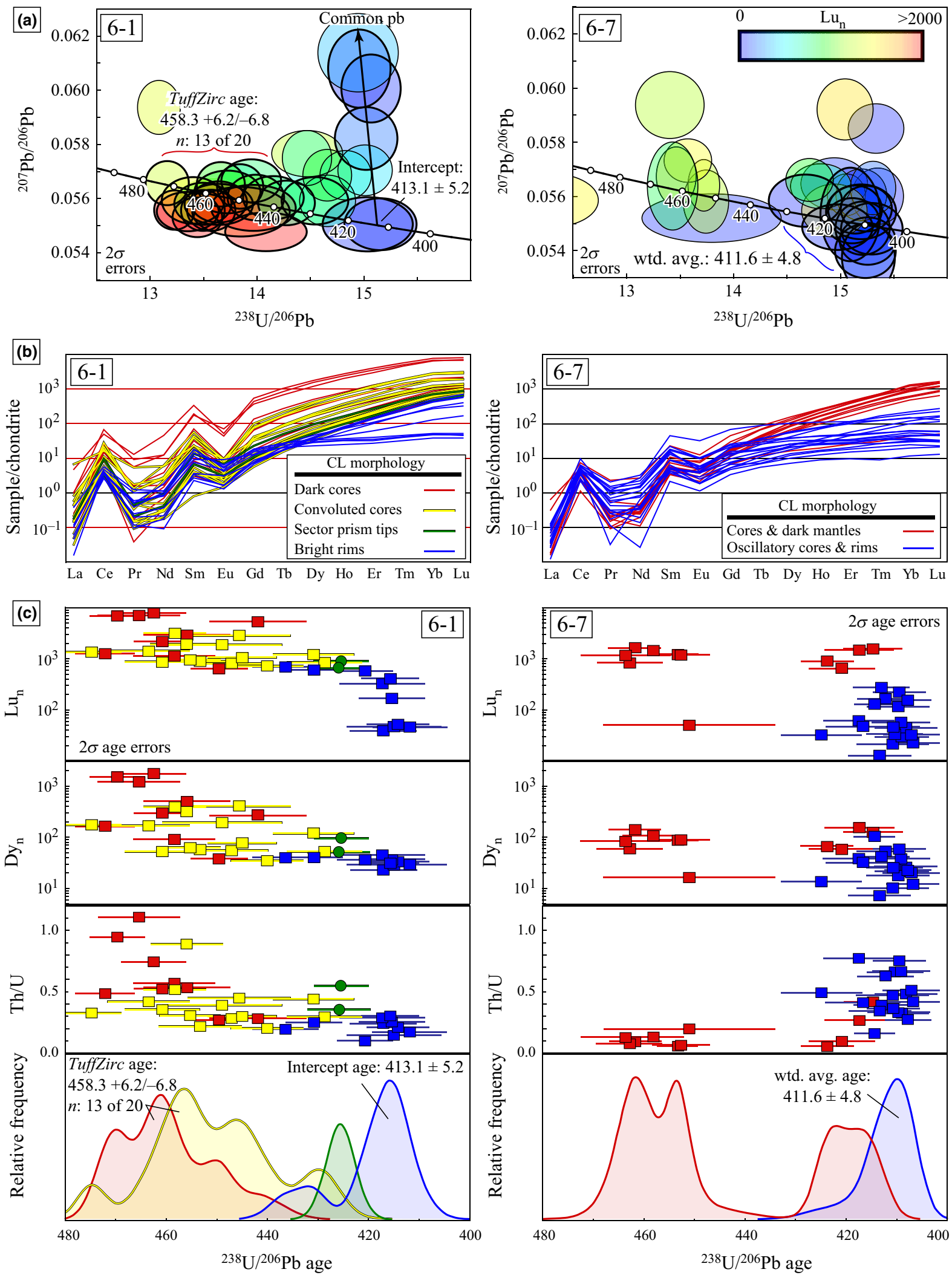

Fig. 8. LASS ICPMS data from metamafic migmatite zircon illustrating (a) U-Pb isotopic data, (b) chondrite-normalized REE plots and (c) trace element ratios with age probability density plots. Error ellipses in (a) indicate $2 \sigma$ internal errors; bold error ellipses indicate analyses used for the age calculations described in the text. Colours in (c) follow the legends from the appropriate sample in (b). 
zircon morphologies that correlate with zircon geochemical signature and $\mathrm{U}-\mathrm{Pb}$ age: (i) prismatic grains with bright to patchy cores and homogenously dark mantles and (ii) equant grains that display oscillatory or sector zoning through grain cores with sporadically developed bright rims up to $15 \mu \mathrm{m}$ thick (Fig. 6). In several grains, oscillatory zoning is developed as thick overgrowths on grains that display relict cores with bright CL characteristic of the first grain morphology population. Grains with bright cores and dark rims have low $\mathrm{Th} / \mathrm{U}<0.1$ and positively sloped HREE profiles with $\mathrm{Lu}_{n}>600$. Four concordant analyses from bright cores yield ${ }^{206} \mathrm{~Pb} /{ }^{238} \mathrm{U}$ ages from 463 to $452 \mathrm{Ma}$, whereas three concordant or nearly concordant analyses from patchy cores or dark mantles yield ${ }^{206} \mathrm{~Pb} /{ }^{238} \mathrm{U}$ ages of 424-417 Ma. In contrast, analyses from oscillatory or sector-zoned cores and their bright rims display younger ${ }^{206} \mathrm{~Pb} /{ }^{238} \mathrm{U}$ ages from 425 to $406 \mathrm{Ma}$, negative $\mathrm{Eu}$ anomalies, generally flat HREE profiles with $\mathrm{Lu}_{n}<270$ and high Th concentrations yielding higher Th/U typically $>0.3$ (Fig. 8).

\section{Timing of geochemically distinct zircon populations}

\section{Pelitic gneiss zircon}

Both samples of pelitic gneiss have zircon rims that are characterized by variable trace element patterns and broad ranges of concordant ages. Concordant zircon rims yield ${ }^{206} \mathrm{~Pb} /{ }^{238} \mathrm{U}$ weighted average ages of $440.3 \pm 5.4$ and $431.5 \pm 4.8 \mathrm{Ma}$ (at $95 \%$ conf.) in samples 6-14 and 6-2.1, respectively, although high MSWDs of 8.7 and 4.7 indicate that the data do not represent single age populations. Single age populations are similarly precluded when analyses are considered as distinct geochemical populations grouped according to HREE concentration. Concordant age ranges in zircon rims may be caused by a variety of processes including mixing during laser ablation of inherited zircon cores with younger rim domains, partial to full recrystallization and $\mathrm{Pb}$-loss from previously crystallized zircon (e.g. Vavra et al., 1999) or alternatively, may indicate the presence of multiple zircon rim populations (e.g. Rubatto et al., 2009; Gilotti et al., 2014). In the data set presented here, we consider inheritance through analytical mixing to be insignificant because (i) analysis locations specifically targeted rims observed in CL; (ii) even subtle contamination of rim analyses by radiogenic $\mathrm{Pb}$ from inherited Mesoproterozoic cores would have forced Ordovician-Devonian rim analyses off concordia; and (iii) LREE and HREE concentrations that are not correlated in sample 6-14, and inversely correlated in sample 6-2.1, are not compatible with linear relationships expected from analytical mixing between REE-rich cores and REE-poor rims. Pb-loss and geochemical disruption through zircon recrystallization is also considered insignificant. Pb-loss is associated with lower $\mathrm{Th} / \mathrm{U}$ and preferential depletion of the LREE and MREE with respect to the HREE in progressively younger analyses (Hoskin \& Black, 2000). Given the lack of any systematic trends between trace-element concentration and age in sample 6-14, and younger analyses that trend towards increasing LREE and $\mathrm{Th} / \mathrm{U}$ in sample 6-2.1 (Fig. 7), there is no evidence suggesting that Pb-loss could have created the range of concordant rim ages.

In lieu of analytical mixing or significant zircon recrystallization, we infer that the range of concordant ages and variable geochemical signatures observed in zircon rims from pelitic gneiss represent multiple zircon rim populations. Geochemically distinct zircon rim populations could have formed via one of two end-member processes: (i) multiple or continuous zircon crystallization events in equilibrium with temporally variable phase assemblages or (ii) protracted crystallization of zircon rims with trace element concentrations controlled by local equilibrium with spatially variable phase assemblages. Without in situ sampling of zircon within the context of adjacent phase assemblages, these end-member processes cannot be distinguished here. As such, rather than assign average ages, we conservatively interpret age probability peaks and associated ranges to date the crystallization of different zircon geochemical populations (e.g. Gilotti et al., 2014). Sample 6-14 formed zircon rims with moderately depleted HREE and severely depleted LREE that grew abundantly at c. $440 \mathrm{Ma}$, and potentially as early as $450 \mathrm{Ma}$ and as late as $420 \mathrm{Ma}$. Sample 6-2.1 formed at least two geochemically distinct populations of zircon rims associated with spatially and/or temporally variable phase assemblages from c. 440 to $425 \mathrm{Ma}$.

\section{Mafic gneiss zircon}

Zircon from the mafic gneiss also displays a range of concordant analyses with variable geochemistry, although when considered with CL imaging and geochemical results, the assigned errors allow age determinations for geochemically distinct zircon populations. In sample 6-1, mixing of REE-rich cores and REE-poor rims during analysis is once again considered insignificant because the analyses do not lie on a mixing line. However, convoluted core domains yield younger ages, lower $\mathrm{Th} / \mathrm{U}$, depleted LREE and MREE, and comparable HREE with respect to dark oscillatory core domains. These trends are consistent with partial recrystallization and $\mathrm{Pb}$-loss of inherited oscillatory cores during a subsequent thermal event (Hoskin \& Black, 2000). Given this assumption of partial recrystallization within grain cores, the TuffZirc algorithm of Ludwig (2003) was used on analyses from all concordant core analyses to statistically eliminate ages affected by Pb-loss, and yielded a ${ }^{206} \mathrm{~Pb} /{ }^{238} \mathrm{U}$ age of $458.3+6.2 /-6.8$ $(97.8 \%$ conf.) that we interpret to date the 
crystallization of inherited HREE-rich cores (Fig. 8). Approximately $425 \mathrm{Ma}$ sector-zoned prism tips with trace element patterns similar to convoluted cores may represent a discrete period of zircon overgrowth, although given the lack of widespread development of this morphology and only one concordant age, this zircon population is not further considered. In contrast, bright zircon rims with flat HREE slopes are ubiquitously developed. When sorted by geochemistry, five analyses from bright rims in three grains yield an age of $413.1 \pm 5.2 \mathrm{Ma}(95 \%$ conf.; MSWD $=0.2$ ) as defined by a common $\mathrm{Pb}$ discord, and which we interpret to date the timing of zircon overgrowths with distinctly depleted HREE concentrations.

Zircon from sample 6-7 yields similar geochemistry and ages to cores and rims from sample 6-1, although in sample 6-7, these zircon populations are most clearly developed in individual grains rather than in core-rim relationships. Several small bright cores with old ages are overgrown by younger sector-zoned rims, however, and indicate that these populations were sporadically developed within the same sections of the rock. When separated by CL morphology and trace-element geochemistry, four of five concordant analyses from bright cores and dark mantles display enriched HREE signatures and yield ages of 463-453 Ma that we loosely interpret as the crystallization age of inherited cores. Three younger ages from the similar bright cores or dark mantles are interpreted to represent partial recrystallization of original inherited zircon. Twelve concordant analyses from oscillatory cores and overgrowths characterized by depleted HREE concentrations yield a ${ }^{206} \mathrm{~Pb} /{ }^{238} \mathrm{U}$ weighted average age of $411.6 \pm 4.8 \mathrm{Ma}$ $(95 \%$ conf., MSWD $=1.7$; Fig. $8 \mathrm{a}, \mathrm{b})$ that we interpret to define a second stage of zircon crystallization and overgrowth.

\section{DISCUSSION}

\section{Zircon petrochronology constraints on the $P-T-t$ path of the Jættedal complex}

The coupled zircon CL imaging, geochemistry and geochronological results from the different rock types presented here allows us to place new constraints on the $P-T-t$ path of the Jættedal complex. Sector and planar-zoning in zircon rims observed in both pelitic gneiss samples is commonly attributed to growth in the presence of a silicate melt (Vavra et al., 1996, 1999; Kelly \& Harley, 2005; Peck et al., 2010), and indicates that these rims likely grew after the appearance of the first melt through muscovite breakdown melting reactions (1a) or (1b). Flat HREE profiles in these rim analyses further indicate that these zircon rims grew in equilibrium with garnet, or after significant fractionation of the HREE into garnet cores before zircon growth (Schaltegger et al., 1999;
Rubatto, 2002; Whitehouse \& Platt, 2003). Widespread evidence for garnet resorption during retrogression, including embayed garnet rims with enriched $X_{\mathrm{Mn}}$ and the reversal of reaction (2) in sample 2.1, suggest that HREE were readily available during cooling and melt crystallization. As such, the depleted HREE zircon rims observed in the Jættedal pelites are not consistent with crystallization during cooling of leucosomal melts (Kelsey et al., 2008). Instead, we interpret these zircon rims to have formed during garnet-stable prograde reactions through a zircon coarsening dissolution-precipitation reaction encouraged by the presence of a $\mathrm{Zr}$-undersaturated silicate melt (Hoskin \& Black, 2000; Peck et al., 2010).

Low $\mathrm{Th} / \mathrm{U}$ and depleted LREE signatures characteristic of the moderate HREE zircon population in both samples indicate that zircon coarsening likely occurred in equilibrium with melts at least locally depleted with respect to Th and the LREE, and/or in local equilibrium with LREE-rich competing accessory phases such as monazite (Bea \& Montero, 1999; Kelly \& Harley, 2005). In contrast, relatively enriched LREE in analyses with severely depleted HREE in sample 2.1 indicate growth in equilibrium with LREE-enriched melts and/or the lack of competing LREE-rich accessory phases. Biotite dehydration melting in sample 6-2.1 is consistent with further fractionation of HREE through continued garnet growth, and increased LREE availability associated with dissolution of monazite in higher melt volumes. As such, we suggest that the younger LREE-rich/ HREE-poor zircon rims in sample 6-2.1 grew during continuous biotite dehydration melting, but not in sample 6-14, which lacks evidence for biotite dehydration. When considered collectively, we interpret the variable trace element patterns and ages from pelitic gneiss zircon rims to date the timing of prograde anatexis associated with muscovite breakdown and subsequent and biotite dehydration in pelitic gneisses from $c .440$ to $425 \mathrm{Ma}$.

Zircon from mafic gneisses documents events that pre- and post-date pelite anatexis. Mafic gneiss zircon with $463-453 \mathrm{Ma}$ cores and positive HREE slopes is distinct from Meso-Neoproterozoic detrital cores and c. 440-425 Ma HREE-poor rim populations observed in the pelitic gneisses, and thus cannot be xenocrysts. Therefore, we interpret the age of $458.3+6.2 /$ $-6.8 \mathrm{Ma}$ determined from sample 6-1 to date the timing of mafic intrusion into the host pelites of the Jættedal complex. Following igneous crystallization, the development of bright rims with lobate boundaries against grain cores in sample 6-1 and heavily corroded zircon cores in sample 6-7 are indicative of zircon dissolution in an aqueous fluid or silicate melt (Gebauer et al., 1997; Ayers et al., 2003; Corfu et al., 2003). Flat HREE slopes in these overgrowths and in equant sector-planar zoned grains indicate subsequent zircon reprecipitation either concurrent with garnet growth, or following fractionation of HREE 
in garnet cores. Because the first appearance of garnet in these rocks is interpreted to coincide with amphibole dehydration melting reaction (6), this population of low HREE zircon is interpreted to have formed in equilibrium with melt rather than with prograde aqueous fluids, and assigns a minimum age of 413-412 Ma to mafic anatexis. Without trace-element data from garnet, zircon equilibrium with garnet cannot be verified. However, resorbed garnet rims indicate garnet breakdown and HREE availability during retrogression, and suggest that this low HREE zircon likely formed at, or near, peak temperatures and prior to retrograde crystallization of the melt.

Together, these zircon petrochronology results document the presence of silicate melts within the Jættedal complex beginning with pelite anatexis from c. 440 to $425 \mathrm{Ma}$ and ending with mafic anatexis at $412 \mathrm{Ma}$. The temporal disparity between pelite and mafic anatexis highlights the dependence of melting reactions on protolith composition, and illustrates the advantages of examining multiple rock types in investigations of high- $T$ terranes (e.g. Gilotti et al., 2014). Here, we interpret the observed melting history as the result of a period of slow heating - from the initiation of pelite anatexis at upper-amphibolite temperatures through mafic anatexis at granulite facies temperatures - that defines $c$. $30 \mathrm{Ma}$ of high- $T$ metamorphism at lower crustal depths. Following this protracted high- $T$ metamorphism, late sillimanite in pelitic gneisses indicates the reversal of reaction (2) and a roughly clockwise $P-T$ evolution. However, the lack of cordierite in pelitic gneisses (this study), together with muscovite cooling ages of $392-378 \mathrm{Ma}$ throughout southern Liverpool Land (Bowman, 2008), suggests gradual cooling in the Jættedal complex rather than isothermal decompression.

\section{Implications for the structural evolution of Liverpool Land}

This evidence for protracted upper-amphibolite-granulite facies metamorphism in the Jættedal complex places new constraints on the structural evolution of the Liverpool Land gneiss complexes. Correlations between the Jættedal complex and other Laurentian terranes are based on detrital zircon ages and the timing of pelitic anatexis (Johnston et al., 2010). These correlations are strengthened here by c. $458 \mathrm{Ma}$ mafic intrusives in the Jættedal complex which overlap with an initial suite of 466-450 Ma calc-alkaline intrusives exposed in Renland and Milne Land farther west (Kalsbeek et al., 2008; Rehnstrom, 2010). In Liverpool Land, these intrusives are correlated with similar granitic rocks that dominate the Hurry Inlet plutonic terrane (Corfu \& Hartz, 2011; Augland et al., 2012) to the north and are structurally higher than the Jættedal complex. Despite this shared Laurentian affinity, granitic rocks of the Hurry Inlet plutonic terrane had crystallized and cooled through titanite closure to $\mathrm{Pb}$ diffusion by $420 \mathrm{Ma}$ (Corfu \& Hartz, 2011), whereas Jættedal complex mafic gneisses indicate granulite facies conditions at temperatures $>800{ }^{\circ} \mathrm{C}$ until at least $412 \mathrm{Ma}$. This variable cooling history suggests that the Hurry Inlet plutonic terrane and the Jættedal complex resided at different structural levels: the Hurry Inlet plutonic terrane cooled gradually following pluton emplacement in the Laurentian middle crust, while the Jættedal complex in the Laurentian lower crust remained hot for at least an additional $8 \mathrm{Ma}$ leading up to, and during collision with, Baltica. Residence at different structural levels requires subsequent exhumation and emplacement of the Jættedal complex against the Hurry Inlet plutonic terrane at middle crustal levels, and supports mapping that places the Jættedal complex in the footwall of the normal-sense Gubbedalen shear zone (e.g. Johnston et al., 2010).

The Jættedal complex is, in turn, structurally underlain by migmatitic orthogneiss terranes with evidence for HP metamorphism. West of Jættedal Valley, the Liverpool Land eclogite terrane consists of orthogneiss with 405-387 Ma migmatitic textures (Johnston et al., 2010; Corfu \& Hartz, 2011) that include rare boudins of garnet peridotite as well as $\mathrm{km}$-scale mafic bodies that experienced 400-397 Ma eclogite facies metamorphism (Augland et al., 2010; Corfu \& Hartz, 2011). East of Jættedal Valley, the Jættedal complex overlies orthogneiss characterized by 409 Ma migmatization (Johnston et al., 2010) that is identical in age to migmatitic orthogneisses that host retrogressed eclogite in the Marianger Fjord Dome $25 \mathrm{~km}$ to the north (Fig. 1a, Corfu \& Hartz, 2011). The 410-395 Ma HP metamorphism and the lack of an Ordovician-Silurian intrusive and metamorphic history in both eclogite-bearing terranes contrast sharply with 460-450 intrusion and 440410 granulite facies metamorphism in the Jættedal complex, and requires that these rocks must have remained in tectonically distinguishable terranes until after HP metamorphism of the migmatitic orthogneiss terranes. Thus, the contact between the Jættedal complex and the structurally lower HP migmatitic orthogneiss terranes represents a lower crustal terrane boundary (i.e. the Ittoqqortoormiit shear zone, Johnston et al., 2010). Although the kinematic evolution of this terrane boundary remains enigmatic, it must be related to an initial phase of mantle exhumation and/or emplacement of HP migmatitic orthogneiss terranes adjacent to the Jættedal complex in the Laurentian lower crust that was subsequently overprinted by normal-sense displacement along the Gubbedalen shear zone.

\section{Thermal patterns and tectonic implications for the Caledonian overriding plate}

These new $P-T-t$ data from the Jættedal complex fill gaps in the thermal history of the southern GC that help define regional metamorphic trends in the over- 
riding plate of the Caledonian orogen. As noted above, the Jættedal complex is closely linked to Laurentian margin terranes exposed farther west. In particular, its history of Silurian pelitic anatexis correlates well with c. 430 Ma upper-amphibolitegranulite facies metamorphism (Leslie \& Nutman, 2003; White \& Hodges, 2003; Gilotti et al., 2008) and crustal melting within Hagar Bjerg thrust sheet extending along the thrust front of the southern GC from Renland to Andrée Land (Watt et al., 2000; Kalsbeek et al., 2001, 2008; Andresen et al., 2007). Similar Silurian anatectic gneiss terranes are also found north of Liverpool Land in Clavering $\varnothing$ and Ardencaple Fjord in the orogenic core of the southern GC (Jones \& Strachan, 2000; Jones \& Escher, 2002; Higgins et al., 2004; Gilotti et al., 2008). Together, these units define a broad region characterized by high geothermal gradients $\geq 20{ }^{\circ} \mathrm{C} \mathrm{km}^{-1}$ and melt-weakened rheology during the Silurian that stretched $\sim 600 \mathrm{~km}$ along strike in the lower to middle crust of the southern GC (Fig. 1). The original width of this weak crust is partially obscured by subsequent post-orogenic extensional structures. Here, we estimate $71 \mathrm{~km}$ of horizontal extension based $\sim 30 \mathrm{~km}$ of vertical throw along on the Fjord Region Detachment System dipping at $25^{\circ}$ (Gilotti \& McClelland, 2008). Subtracting this estimate from a current width of at least $280 \mathrm{~km}$ spanning exposures in the fjords east of Milne Land to Liverpool Land (Higgins et al., 2004) suggests that this melt-weakened middle to lower crust originally stretched $>200 \mathrm{~km}$ perpendicular to orogenic strike during the Silurian.

Despite this shared Silurian metamorphic history with the Hagar Bjerg thrust sheet, the Jættedal complex displays evidence for a significantly longer residence time in the Laurentian lower crust. Pelites from the Hagar Bjerg thrust sheet near the thrust front yield $P-T-t$ paths indicative of isothermal decompression following peak metamorphic conditions (White \& Hodges, 2003), while 420-409 Ma muscovite cooling ages from associated S-type granites indicate rapid cooling following Silurian anatexis (Hartz et al., 2001; White \& Hodges, 2002). In contrast, farther east and in the orogenic core, Silurian anatectic pelites in Ardencaple Fjord display moderate retrograde $P-T$ trajectories (Jones \& Strachan, 2000) and a foliated granite yields a muscovite cooling age of $385 \mathrm{Ma}$ (Dallmeyer et al., 1994). This protracted high- $T$ history is similar to the $P-T-t$ evolution of the Jættedal complex documented here. Evidence for high- $T$ metamorphism in the Devonian is documented near the thrust front in the Niggli Spids thrust sheet by 404-403 Ma anatexis in Payer Land (McClelland \& Gilotti, 2003). However, the Niggli Spids thrust sheet in Payer Land experienced high- $P$ granulite facies conditions along a relatively cool geotherm (Fig. 9) and lacks evidence for earlier Silurian anatexis. Thus, the Jrttedal complex and correlative terranes displaying Silurian anatexis are not considered to be cogenetic with the Niggli Spids thrust sheet. The emerging regional metamorphic pattern suggests that the broad zone of thermally weakened crust in the southern GC during the Silurian

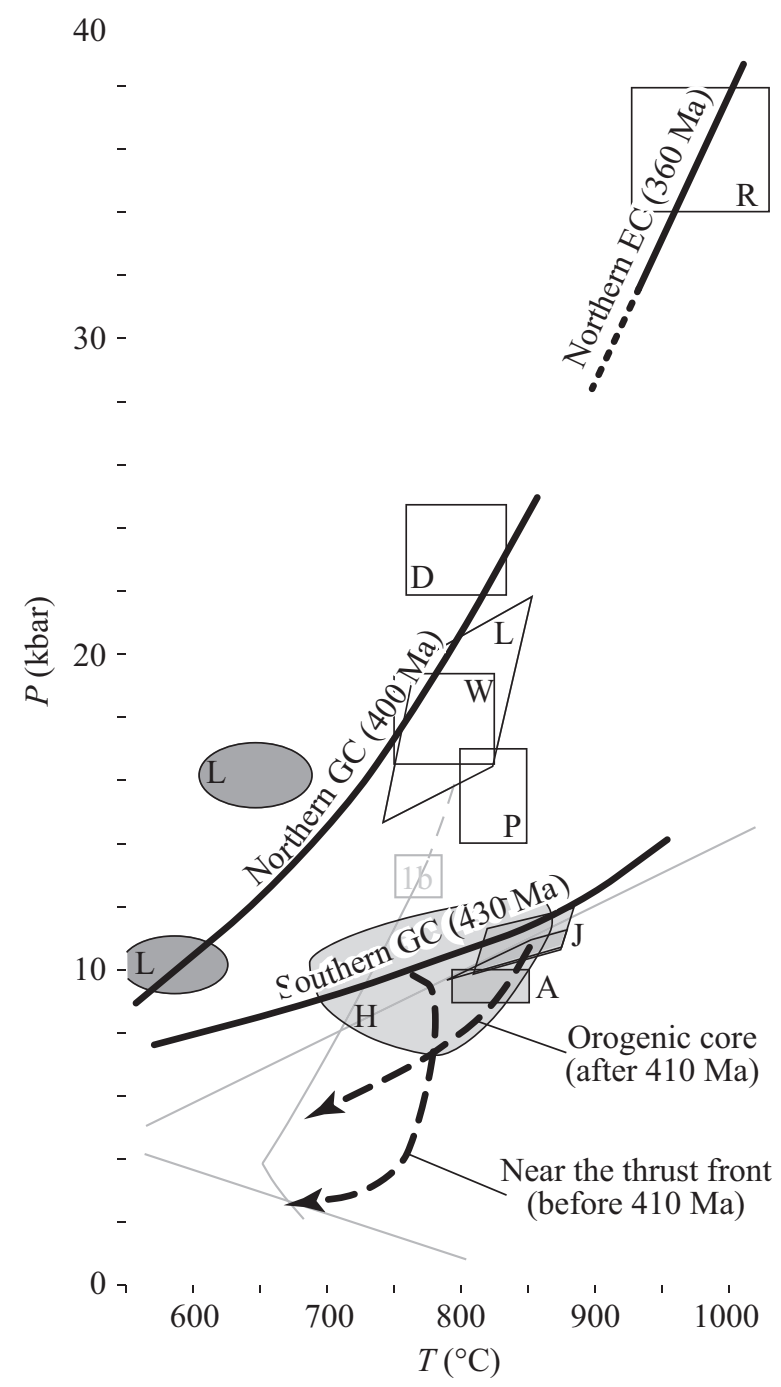

Fig. 9. Plot illustrating the regional metamorphic patterns documented in the Greenland Caledonides (CG). Aluminium silicate equilibria and reaction (1b) from the NaCKFMASH grid of Spear et al. (1999) are plotted in light grey for reference. Note that the cooler geothermal gradient in the northern GC plots below muscovite dehydration reaction (1b) predicting a melt-poor, strong middle to lower crust, and contrasts sharply with the melt-weakened middle crust predicted by the hotter geotherm in the southern GC. Thick dotted lines illustrate the diachronous and variable exhumation paths for Silurian anatectic rocks near the thrust front and in the orogenic core of the southern EGC. Abbreviations with $P-T$ estimates refer to A: Ardencaple Fjord (Jones \& Strachan, 2000); Danmarkshavn (Brueckner et al., 1998; Gilotti et al., 2008); H: Hagar Bjerg thrust sheet (White \& Hodges, 2003); J: Jættedal complex, Liverpool Land (this study); L: Lambert Land (Gilotti et al., 2008); P: Payer Land (Gilotti \& Elvevold, 2002; Elvevold et al., 2003); R: Rabbit Ears Island (Gilotti \& Krogh Ravna, 2002); W: Weinschenk Ø (Elvevold \& Gilotti, 2000). 
experienced spatially different exhumation paths: the Hagar Bjerg thrust sheet near the thrust front of the southern GC experienced rapid exhumation following anatexis, whereas Silurian anatectic terranes in the orogenic core of the southern GC remained trapped at lower crustal levels until subsequent exhumation with structurally lower units (Fig. 9).

Rapid exhumation of the Hagar Bjerg thrust sheet near the thrust front is thought to be representative of Silurian syn-orogenic extension, perhaps analogous to recent Himalayan extension along the South Tibetan detachment (Hartz et al., 2001; White et al., 2002; Andresen et al., 2007; Gilotti \& McClelland, 2008). Kinematic models developed to describe the evolution of syn-orogenic extensional structures suggest normal-sense displacement either along the upper boundary of a ductile lower to middle crustal channel (e.g. Beaumont et al., 2001) or in response to wedge instabilities above a growing critical taper nappe stack (e.g. Kohn, 2008). Kohn (2008) proposed using the spatial scale of high-grade metamorphic conditions capable of flow at any given time to differentiate between these endmember models: whereas steady-state critical taper predicts the localized development of crustal flow over million year time-scales, channel flow requires the regional development of a weak lower to middle crust active for tens of millions of years. The correlation of thermally weakened lower to middle crust in the Hagar Bjerg thrust sheet and the Jættedal complex define a region $>200 \mathrm{~km}$ perpendicular to strike and capable of flow, and thus supports channel flow as a mechanism for Silurian syn-orogenic exhumation near the thrust front of the southern GC. Protracted high- $T$ metamorphism described in the Jættedal complex here, as well as suggested by studies from Ardencaple Fjord (Dallmeyer et al., 1994; Jones \& Strachan, 2000), indicates that portions of this channel in the orogenic core were trapped in the lower crust.

The recognition of a protracted weak lower crust in the orogenic core of the southern GC highlights variable modes of Devonian-Carboniferous deformation observed along strike in the GC. The northern GC is characterized by a series of westward-propagating thrust sheets that increase in the metamorphic grade up structural section from sedimentary rocks in the west to high-grade gneisses in the North-East Greenland eclogite province that reached HP and UHP metamorphic conditions by 414-393 and 365$350 \mathrm{Ma}$ respectively (Gilotti et al., 2004, 2008, 2014). Paleoproterozoic inherited zircon cores from the North-East Greenland eclogite province demonstrate Laurentian provenance (Gilotti \& McClelland, 2011), and are suggestive of intracontinental subduction in the Caledonian overriding plate (Gilotti \& McClelland, 2007). The northern GC thrust architecture is cut by regional-scale strike-slip faults active into the Carboniferous (Sartini-Rideout et al., 2006), but lacks significant development of Devonian extensional structures. In contrast, the southern GC are characterized by the development of regional Devonian post-orogenic extensional structures (White \& Hodges, 2002; McClelland \& Gilotti, 2003; Gilotti \& McClelland, 2008). Furthermore, tentative correlations between the Liverpool Land eclogite terrane and the Marianger Fjord Dome with the Western Gneiss Complex of Baltica have been made based on 1700-1600 Ma protolith ages from orthogneisses and mafic bodies, the presence of garnet peridotite and the Devonian timing of high- $P$ metamorphism (Augland, 2007; Johnston et al., 2010; Augland et al., 2011; Corfu \& Hartz, 2011). While these correlations are still a matter for debate (see discussion in Corfu \& Hartz, 2011), they are suggestive of terrane transfer of eclogite facies rocks from the subducted Baltican plate into the overriding Laurentian plate during Caledonian orogenesis (Johnston et al., 2010; Augland et al., 2011; Corfu \& Hartz, 2011), and contrast with intracontinental subduction in the northern GC.

These contrasting styles of deformation and HP metamorphism are spatially coincident with corresponding differences in the Devonian thermal structure of the Laurentian overriding plate. Cold geotherms $<15{ }^{\circ} \mathrm{C} \mathrm{km}^{-1}$ at all structural levels during 414-393 Ma HP metamorphism in the northern GC (Brueckner et al., 1998; Gilotti et al., 2004, 2008) contrast sharply with granulite facies anatexis in the Jættedal complex at $412 \mathrm{Ma}$ indicating geotherms at least locally $>20{ }^{\circ} \mathrm{C} \mathrm{km}^{-1}$ in the orogenic core of the southern GC (Fig. 9). Because the presence of melt is governed by dehydration reactions in crustal rocks, this variability in thermal structure predicts a corresponding variation in the strength of the Caledonian overriding plate prior to, and during, LaurentiaBaltica collision: hotter geotherms in the southern GC are consistent with melt-present, weak crust, whereas cooler geotherms in the northern GC preclude melting until greater depths, and a yield meltpoor, stronger crust. Thermal-mechanical models investigating continental collisions suggest that terrane transfer following continental subduction may occur through relamination beneath the leading edge of the overriding continental plate, or more distally as rising diapirs through the mantle wedge (Yin et al., 2007; Sizova et al., 2012), whereas weaker conditions in the overriding plate are shown to encourage extrusion of subducted continental material into the overriding plate (Butler et al., 2011). Although further work detailing the kinematic evolution and provenance of HP terranes in Liverpool Land is clearly necessary, these thermal-mechanical models and the evidence for a protracted weak lower crust in the Jættedal complex are consistent with the possibility of terrane transfer of subducted Baltican crust into the overriding Laurentian plate in Liverpool Land. Parallel reasoning suggests that stronger 
crustal conditions in the northern GC may have prohibited terrane transfer and led to intracontinental subduction. Furthermore, we speculate that the spatial coincidence of a weak lower crust in the orogenic core of the southern GC and post-orogenic extensional structures can be explained if ascent and underplating of subducted Baltican crust localized Caledonian Devonian extension in the southern and central Caledonides (e.g. Fossen, 2010).

\section{CONCLUSIONS}

We present new metamorphic petrology and coupled zircon geochronology and geochemistry to quantify the metamorphic evolution of the Jættedal complex structurally above the Liverpool Land eclogite terrane in the East GC. Our results indicate:

(1) Approximately $460-450 \mathrm{Ma}$ intrusion of mafic dykes in southern Liverpool Land,

(2) Upper amphibolite-granulite facies anatexis in Jættedal complex metapelites from c. 440 to $425 \mathrm{Ma}$, and

(3) Granulite facies anatexis of Jættedal complex mafic migmatites at c. $412 \mathrm{Ma}$.

The timing of protracted high- $T$ metamorphism in the Jættedal complex indicates that it resided at significantly lower crustal levels than the overlying Hurry Inlet plutonic complex, and in the footwall of the extensional Gubbedalen shear zone. This result supports two-stage exhumation models for the Liverpool Land eclogite terrane with initial exhumation and juxtaposition with the Jættedal complex closely followed by exhumation of both terranes along the extensional Gubbedalen shear zone. The correlation of the Jættedal complex with the Hagar Bjerg thrust sheet defines a broad region $>200 \mathrm{~km}$ perpendicular to orogenic strike in the southern GC characterized by high geothermal gradients and a weak lower to middle crust during the Silurian. However, the presence of migmatitic rocks until at least $412 \mathrm{Ma}$ in Jættedal complex indicates that while this weak lower to middle crust was rapidly exhumed near the thrust front, it remained in the lower crust at high temperature in the orogenic core. This persistent hot lower crust in the core of the southern GC contrasts sharply with cooler geothermal gradients in the northern GC, and suggests that along-strike variation in the thermal structure of orogenic overriding plates plays a significant role in the style of collisional orogenesis including the mode of (U)HP burial and exhumation, and the development of post-orogenic collapse structures.

\section{ACKNOWLEDGEMENTS}

This work was supported by NSF-EAR 0838530 to Johnston and Brueckner. We thank E. Hartz for providing field equipment, A. Lynge for help with field logistics, K. Agustsson for field and laboratory assistance, and B. Hacker for discussions on the data and their implications. This manuscript has benefitted from editorial comments and constructive reviews by J. Gilotti and F. Corfu.

\section{REFERENCES}

Andresen, A., Rehnström, E.F. \& Holte, M., 2007. Evidence for simultaneous contraction and extension at different structural levels during the Caledonian orogeny in NE Greenland. Journal of the Geological Society of London, 164, 869-880.

Augland, L., 2007. The Gubbedalen Shear Zone: A Terrane Boundary in the East Greenland Caledonides. Unpublished MS thesis, University of Oslo, Norway.

Augland, L., Andresen, A. \& Corfu, F., 2010. Age, structural setting, and exhumation of the Liverpool Land eclogite terrane, East Greenland Caledonides. Lithosphere, 2, 267-286.

Augland, L., Andresen, A. \& Corfu, F., 2011. Terrane transfer during the Caledonian orogeny: Baltican affinities of the Liverpool Land Eclogite Terrane in East Greenland. Journal of the Geological Society of London, 168, 15-26.

Augland, L., Andresen, A., Corfu, F. \& Daviknes, H.K., 2012. Late Ordovician to Silurian ensialic magmatism in Liverpool Land, East Greenland: new evidence extending the northeastern branch of the continental Laurentian magmatic arc. Geological Magazine, 149, 561-577.

Ayers, J.C., DeLaCruz, K., Miller, C. \& Switzer, O., 2003. Experimental study of zircon coarsening in quartzite $\pm \mathrm{H}_{2} \mathrm{O}$ at $1.0 \mathrm{GPa}$ and $1000^{\circ} \mathrm{C}$, with implications for geochronological studies of high-grade metamorphism. American Mineralogist, 88, 365-376.

Bea, F. \& Montero, P., 1999. Behavior of accessory phases and redistribution of $\mathrm{Zr}, \mathrm{REE}, \mathrm{Y}, \mathrm{Th}$, and $\mathrm{U}$ during metamorphism and partial melting of metapelites in the lower crust: an example from the Kinzigite Formation of IvreaVerbano, NW Italy. Geochimica Cosmochimica Acta, 63, $1133-1153$.

Beaumont, C., Jamieson, R.A., Nguyen, M.H. \& Lee, B., 2001. Himalayan tectonics explained by extrusion of a lowviscosity crustal channel coupled to focused surface denudation. Nature, 414, 738-742.

Bird, P., 1991. Lateral extrusion of lower crust from under high topography, in the isostatic limit. Journal of Geophysical Research, 96, 10275-10286.

Bohlen, S.R. \& Liotta, J.L., 1986. A barometer for garnet amphibolites and garnet granulites. Journal of Petrology, 27, $1025-1034$.

Bowman, D.R., 2008. Exhumation History of Caledonian Eclogites in Liverpool Land, East Greenland, and Comparisons with Eclogites in Norway. Unpublished MS thesis, Auburn University.

Brueckner, H.K., Gilotti, J.A. \& Nutman, A.P., 1998. Caledonian eclogite-facies metamorphism of Early Proterozoic protoliths from the North-East Greenland Eclogite Province. Contributions to Mineralogy and Petrology, 130, 103-120.

Butler, J.P., Beaumont, C. \& Jamieson, R.A., 2011. Crustal emplacement of exhuming (ultra)high-pressure rocks: will that be pro- or retro-side? Geology, 39, 635-638.

Carrington, D.P. \& Harley, S.L., 1995. Partial melting and phase relations in high-grade metapelites: an experimental petrogenetic grid in the KFMASH system. Contributions to Mineralogy and Petrology, 120, 270-291.

Carswell, D.A., Brueckner, H.K., Cuthbert, S.J., Mehta, K. \& O'Brien, P.J., 2003. The timing of stabilisation and the exhumation rate for ultra-high pressure rocks in the Western Gneiss Region of Norway. Journal of Metamorphic Geology, 21, 601-612. 
Chemenda, A.I., Burg, J.-P. \& Mattauer, M., 2000. Evolutionary model of the Himalaya-Tibet system: geopoem: based on new modelling, geological and geophysical data. Earth and Planetary Science Letters, 174, 397-409.

Corfu, F. \& Hartz, E.H., 2011. U-Pb geochronology in Liverpool Land and Canning Land, East Greenland - the complex record of a polyphase Caledonian orogeny. Canadian Journal of Earth Sciences, 48, 473-494.

Corfu, F., Hanchar, J.M., Hoskin, P.W.O. \& Kinny, P.D., 2003. Atlas of zircon textures. Reviews in Mineralogy and Geochemistry, 53, 469-500.

Dallmeyer, R.D., Strachan, R.A. \& Henriksen, N., 1994 ${ }^{40} \mathrm{Ar} /{ }^{39} \mathrm{Ar}$ mineral age record in NE Greenland: implications for tectonic evolution of the North Atlantic Caledonides. Journal of the Geological Society of London, 151, 615-628.

Ellis, D.J. \& Green, D.H., 1979. An experimental study of the effect of $\mathrm{Ca}$ upon garnet-clinopyroxene $\mathrm{Fe}-\mathrm{Mg}$ exchange equilibria. Contributions to Mineralogy and Petrology, 71, $13-22$.

Elvevold, S. \& Gilotti, J.A., 2000. Pressure-temperature evolution of retrogressed kyanite eclogites, Weinschenk Island, north-east Greenland Caledonides. Lithos, 53, 127-147.

Elvevold, S., Thrane, K. \& Gilotti, J.A., 2003. Metamorphic history of high-pressure granulites in Payer Land, Greenland Caledonides. Journal of Metamorphic Geology, 21, 49-63.

Ferry, J. \& Spear, F., 1978. Experimental calibration of the partitioning of $\mathrm{Fe}$ and $\mathrm{Mg}$ between biotite and garnet. Contributions to Mineralogy and Petrology, 66, 113-117.

Fossen, H., 2010. Extensional tectonics in the North Atlantic Caledonides: a regional view. In: Continental Tectonics and Mountain Building: The Legacy of Peach and Horne (eds Law, R.D., Butler, R.W., Holdsworth, R.E., Krabbendam, M. \& Strachan, R.A.), Geological Society of London, Special Publications, 335, 767-793.

Friderichsen, J.D. \& Surlyk, F., 1981. 70 Ø.1 Nord, Hurry Inlet; $1: 100,000 ; 71^{\circ} 00^{\prime} \mathrm{N}-70^{\circ} 30^{\prime} \mathrm{N} ; 2^{\circ} 39^{\prime} \mathrm{W}-21^{\circ} 18^{\prime} \mathrm{W}$. Geological Survey of Denmark and Greenland, Copenhagen, Denmark.

Gebauer, D., Schertl, H.-P., Brix, M. \& Schreyer, W., 1997. $35 \mathrm{Ma}$ old ultrahigh-pressure metamorphism and evidence for very rapid exhumation in the Dora Maira massif, Western Alps. Lithos, 41, 5-24.

Gee, D.G., 1975. A tectonic model for the central part of the Scandinavian Caledonides. American Journal of Science, 275A, 468-515.

Gilotti, J.A. \& Elvevold, S., 2002. Extensional exhumation of high-pressure granulite terrane in Payer Land, Greenland Caledonides: structural, petrologic and geochronologic evidence from metapelites. Canadian Journal of Earth Sciences, 39, 1169-1187.

Gilotti, J.A. \& Krogh Ravna, E., 2002. First evidence for ultrahigh-pressure metamorphism in the North-East Greenland Caledonides. Geology, 30, 551-554.

Gilotti, J.A. \& McClelland, W.C., 2007. Characteristics of, and a tectonic model for, ultrahigh-pressure metamorphism in the overriding plate of the Caledonian orogen. International Geology Review, 49, 777-797.

Gilotti, J.A. \& McClelland, W.C., 2008. Geometry, kinematics, and timing of extensional faulting in the Greenland Caledonides - a synthesis. In: The Greenland Caledonides: Evolution of the Northeast Margin of Laurentia (eds Higgins, A.K., Gilotti, J.A. \& Smith, M.P.), Geological Society of America Memoir, 202, 251-271.

Gilotti, J.A. \& McClelland, W.C., 2011. Geochemical and geochronological evidence that the North-East Greenland ultrahigh-pressure terrane is Laurentian crust. The Journal of Geology, 119, 439-456.

Gilotti, J.A., Nutman, A.P. \& Brueckner, H.K., 2004. Devonian to Carboniferous collision in the Greenland Caledonides: U-Pb zircon and $\mathrm{Sm}-\mathrm{Nd}$ ages of high-pressure and ultrahigh-pressure metamorphism. Contributions to Mineralogy and Petrology, 148, 216-235.

Gilotti, J.A., Jones, K.A. \& Elvevold, S., 2008. Caledonian metamorphic patterns in Greenland. In: The Greenland Caledonides: Evolution of the Northeast Margin of Laurentia (eds Higgins, A.K., Gilotti, J.A. \& Smith, M.P.), Geological Society of America Memoir, 202, 201-225.

Gilotti, J.A., McClelland, W.C. \& Wooden, J.L., 2014. Zircon captures exhumation of an ultrahigh-pressure terrane, North-East Greenland Caledonides. Gondwana Research, 25, 235-256.

Gordon, S.M., Luffi, P., Hacker, B. et al., 2012. The thermal structure of continental crust in active orogens: insight from Miocene eclogite and granulite xenoliths of the Pamir Mountains. Journal of Metamorphic Geology, 30, 413-434.

Hacker, B.R., Gnos, E., Ratschbacher, L. et al., 2000. Hot and dry xenoliths from the lower crust of Tibet. Science, 287, 2463-2466.

Hacker, B., Luffi, P., Lutkov, V. et al., 2005. Near-ultrahigh pressure processing of continental crust: Miocene crustal xenoliths from the Pamir. Journal of Petrology, 46, 16611687.

Hacker, B.R., Kelemen, P.B. \& Behn, M.D., 2011. Differentiation of the continental crust by relamination. Earth and Planetary Science Letters, 307, 501-516.

Haller, J., 1971. Geology of the East Greenland Caledonides. Interscience, London.

Hartel, T. \& Pattison, D., 1996. Genesis of the Kapuskasing (Ontario) migmatitic mafic granulites by dehydration melting of amphibolite: the importance of quartz to reaction progress. Journal of Metamorphic Geology, 14, 591-611.

Hartz, E., Andresen, A., Hodges, K.V. \& Martin, M.W., 2001. Syncontractional extension and exhumation of deep crustal rocks in the east Greenland Caledonides. Tectonics, 20, 58-77.

Higgins, A.K., Elvevold, S., Escher, J.C. et al., 2004. The foreland-propagating thrust architecture of the East Greenland Caledonides, $72^{\circ}-75^{\circ}$ N. Journal of the Geological Society of London, 161, 1009-1026.

Higgins, A.K., Gilotti, J.A. \& Smith, M.P., 2008. The Greenland Caledonides: Evolution of the Northeast Margin of Laurentia, Vol. 202. Geological Society of America Memoir, Boulder, CO.

Hoisch, T.D., 1990. Empirical calibration of six geobarometers for the mineral assemblage quartz + muscovite + biotite + plagioclase + garnet. Contributions to Mineralogy and Petrology, 104, 225-234.

Hoisch, T., 1991. Equilibria within the mineral assemblage quartz + muscovite + biotite + garnet + plagioclase, and implications for the mixing properties of octahedrally-coordinated cations in muscovite and biotite. Contributions to Mineralogy and Petrology, 108, 43-54.

Hoskin, P.W.O. \& Black, L.P., 2000. Metamorphic zircon formation by solid-state recrystallization of protolith igneous zircon. Journal of Metamorphic Geology, 18, 423-439.

Johnston, S.M., Hartz, E.H., Brueckner, H.K. \& Gehrels, G.G., 2010. U-Pb zircon geochronology and tectonostratigraphy of southern Liverpool Land, East Greenland: implications for deformation in the overriding plates of continental collisions. Earth and Planetary Science Letters, 297, 512-524.

Jones, K.A. \& Escher, J.C., 2002. Near-isothermal decompression within a clockwise P-T evolution recorded in migmatitic mafic granulites from Clavering $\varnothing, \mathrm{NE}$ Greenland: implications for the evolution of the Caledonides. Journal of Metamorphic Geology, 20, 365-378.

Jones, K.A. \& Strachan, R.A., 2000. Crustal thickening and ductile extension in the NE Greenland Caledonides: a metamorphic record from anatectic pelites. Journal of Metamorphic Geology, 18, 719-735.

Kalsbeek, F., Jepsen, H.F. \& Nutman, A.P., 2001. Geochemistry and petrogenesis of S-type granites in the East Greenland Caledonides. Lithos, 57, 1-21. 
Kalsbeek, F., Higgins, A.K., Jepsen, H.F. \& Frei, R., 2008. Granites and granites in East Greenland Caledonides. In: The Greenland Caledonides: Evolution of the Northeast Margin of Laurentia (eds Higgins, A.K., Gilotti, J.A. \& Smith, M.P.), Geological Society of America Memoir, 202, 227-249.

Kelly, N.M. \& Harley, S.L., 2005. An integrated microtextural and chemical approach to zircon geochronology: refining the Archaean history of the Napier Complex, east Antarctica. Contributions to Mineralogy and Petrology, 149, 57-84.

Kelsey, D.E., Clark, C. \& Hand, M., 2008. Thermobarometric modelling of zircon and monazite growth in melt-bearing systems: examples using model metapelitic and metapsammitic granulites. Journal of Metamorphic Geology, 26, 199212.

Kohn, M.J., 2008. P-T-t data from central Nepal support critical taper and repudiate large-scale channel flow of the Greater Himalayan Sequence. Geological Society of America Bulletin, 120, 259-273.

Koziol, A.M. \& Newton, R.C., 1988. Redetermination of the anorthite breakdown reaction and improvement of the plagioclase-garnet- $\mathrm{Al}_{2} \mathrm{SiO}_{5}$-quartz geobarometer. American Mineralogist, 73, 216-223.

Kylander-Clark, A., Hacker, B. \& Cottle, J., 2013. Laser-ablation split-stream ICP petrochronology. Chemical Geology, 345, 99-112.

Leslie, A.G. \& Nutman, A.P., 2003. Evidence for Neoproterozoic orogenesis and early high temperature Scandian deformation events in the southern East Greenland Caledonides. Geological Magazine, 3, 309-333.

López, S. \& Castro, A., 2001. Determination of the fluid-absent solidus and supersolidus phase relationships of MORBderived amphibolites in the range 4-14 kbar. American Mineralogist, 86, 1396-1403.

Ludwig, K., 2003. User's Manual for Isoplot 3.00. A Geochronological Toolkit for Microsoft Excel. Special Publication, No. 4. Berkeley Geochronology Center, Berkeley, CA, USA.

McClelland, W.C. \& Gilotti, J.A., 2003. Late-stage extensional exhumation of high-pressure granulites in the Greenland Caledonides. Geology, 31, 259-262.

Nelson, K.D., Zhao, W., Brown, L.D., et al., 1996. Partially molten middle crust beneath southern Tibet: synthesis of Project INDEPTH results. Science, 274, 1684-1688.

Newton, R.C. \& Perkins, D.I., 1982. Thermodynamic calibration of geobarometers based on the assemblages garnet-plagioclase-orthopyroxene (clinopyroxene)-quartz. American Mineralogist, 67, 203-222.

Owens, T.J. \& Zandt, G., 1997. Implications of crustal property variations for models of Tibetan plateau evolution. $\mathrm{Na}$ ture, 387, 37-43.

Patiño Douce, A.E. \& Harris, N., 1998. Experimental constraints on Himalayan Anatexis. Journal of Petrology, 39, 689-710.

Pattison, D., 2003. Petrogenetic significance of orthopyroxenefree garnet + clinopyroxene + plagioclase \pm quartz-bearing metabasites with respect to the amphibolite and granulite facies. Journal of Metamorphic Geology, 21, 21-34.

Peck, W.H., Bickford, M.E., McLelland, J., Nagle, A.N. \& Swarr, G., 2010. Mechanism of metamorphic zircon growth in a granulite-facies quartzite, Adirondack Highlands, Grenville Province, New York. American Mineralogist, 95, 17961806.

Powell, R. \& Holland, T.J.B., 1988. An internally consistent dataset with uncertainties and correlations: 3. Applications to geobarometry, worked examples and a computer program. Journal of Metamorphic Geology, 6, 173-204.

Rehnstrom, E.F., 2010. Prolonged Paleozoic magmatism in the East Greenland Caledonides: some constraints from U-Pb Ages and Hf Isotopes. The Journal of Geology, 118, 447-465.

Roberts, D., 2003. The Scandinavian Caledonides: event chronology, paleogeographic settings and likely modern analogues. Tectonophysics, 365, 283-299.
Roberts, D. \& Gee, D.G., 1985. An introduction to the structure of the Scandinavian Caledonides. In: The Caledonide Orogen-Scandinavia and Related Areas (eds Gee, D.G. \& Sturt, B.A.), pp. 55-68. John Wiley and Sons, Chichester.

Root, D.B., Hacker, B.R., Mattinson, J.M. \& Wooden, J.L., 2004. Young age and rapid exhumation of Norwegian ultrahigh-pressure rocks: an ion microprobe and chemical abrasion study. Earth and Planetary Science Letters, 228, 325341.

Royden, L.H., Burchfiel, B.C., King, R.W. et al., 1997. Surface deformation and lower crustal flow in eastern Tibet. Science, 279, 788-790.

Rubatto, D., 2002. Zircon trace element geochemistry: partitioning with garnet and the link between U-Pb ages and metamorphism. Chemical Geology, 184, 123-138.

Rubatto, D., Hermann, J., Berger, A. \& Engi, M., 2009. Protracted fluid-induced melting during Barrovian metamorphism in the Central Alps. Contributions to Mineralogy and Petrology, 158, 703-722.

Rushmer, T., 1993. Experimental high pressure granulites: some applications to natural mafic xenolith suites and Archean granulite terranes. Geology, 21, 411-414.

Sartini-Rideout, C., Gilotti, J.A. \& McClelland, W.C., 2006. Geology and timing of dextral strike-slip shear zones in Danmarkshavn, North-East Greenland Caledonides. Geological Magazine, 143, 431-446.

Schaltegger, U., Fanning, C.M., Günther, D., Maurin, J.C., Schulmann, K. \& Gebauer, D., 1999. Growth, annealing and recrystallization of zircon and preservation of monazite in high-grade metamorphism: conventional and in-situ U-Pb isotope, cathodoluminescence and microchemical evidence. Contributions to Mineralogy and Petrology, 134, 186-201.

Sizova, E., Gerya, T. \& Brown, M., 2012. Exhumation mechanisms of melt-bearing ultrahigh pressure crustal rocks during collision of spontaneously moving plates. Journal of Metamorphic Geology, 30, 927-955.

Spear, F. \& Kohn, M., 1996. Trace element zoning in garnet as a monitor of crustal melting. Geology, 24, 1099-1102.

Spear, F. \& Parrish, R.R., 1996. Petrology and cooling rates of the Valhalla Complex, British Columbia, Canada. Journal of Petrology, 97, 733-765.

Spear, F., Kohn, M. \& Cheney, J., 1999. P-T paths from anatectic pelites. Contributions to Mineralogy and Petrology, 134, 17-32.

Vavra, G., Gebauer, D., Schmid, R. \& Compston, W., 1996. Multiple zircon growth and recrystallization during polyphase Late Carboniferous to Triassic metamorphism in granulites of the Ivrea Zone (Southern Alps): an ion microprobe (SHRIMP) study. Contributions to Mineralogy and Petrology, 122, 337-358.

Vavra, G., Schmidt, R. \& Gebauer, D., 1999. Internal morphology, habit and U-Th-Pb microanalysis of amphibolite to granulite facies zircons: geochronology of the Ivrea Zone (Southern Alps). Contributions to Mineralogy and Petrology, 134, 380-404.

Vielzeuf, D. \& Holloway, J.R., 1988. Experimental determination of the fluid-absent melting relations in the pelitic system. Consequences for crustal differentiation. Contributions to Mineralogy and Petrology, 98, 257-276.

Walsh, E.O., Hacker, B., Gans, P., Grove, M. \& Gehrels, G., 2007. Protolith ages and exhumation histories of (ultra)highpressure rocks across the Western Gneiss Region, Norway. Geological Society of America Bulletin, 119, 289-301. doi:10.1130/B25817.1.

Watt, G.R., Kinny, P.D. \& Friderichsen, J.D., 2000. U-Pb geochronology of Neoproterozoic and Caledonian tectonothermal events in the East Greenland Caledonides. Journal of the Geological Society of London, 157, 1031-1048.

White, A.P. \& Hodges, K.V., 2002. Multistage extensional evolution of the central East Greenland Caledonides. Tectonics, 21, doi:10.1029/2001TC001308. 
White, A.P. \& Hodges, K.V., 2003. Pressure-temperature-time evolution of the Central East Greenland Caledonides: quantitative constraints on crustal thickening and synorogenic extension. Journal of Metamorphic Geology, 21, 875-897.

White, A.P., Hodges, K.V., Martin, M.W. \& Andresen, A., 2002. Geologic constraints on middle-crustal behavior during broadly synorogenic extension in the central East Greenland Caledonides. International Journal of Earth Sciences, 91, 187-208.

Whitehouse, M.J. \& Platt, J.P., 2003. Dating high-grade metamorphism - constraints from rare-earth elements in zircon and garnet. Contributions to Mineralogy Petrology, 145, 6174.

Whitney, D.L. \& Evans, B.W., 2010. Abbreviations for names of rock-forming minerals. American Mineralogist, 95, 185187.

Wiedenbeck, M., Alle, P., Corfu, F. et al., 1995. Three natural zircon standards for U-Th-Pb, Lu-Hf, trace element, and REE analyses. Geostandards Newsletter, 19, 1-23.

Winther, K. \& Newton, R., 1991. Experimental melting of hydrous low-K tholeiite: evidence on the origin of Archaean cratons. Bulletin of the Geological Society of Denmark, 39, 213-228.

Wolf, M. \& Wyllie, P., 1993. Garnet growth during amphibolite anatexis: implications of a garnetiferous restite. Journal of Geology, 101, 357-373.

Wolf, M. \& Wyllie, P., 1994. Dehydration-melting of amphibolite at 10 kbar: the effects of temperature and time. Contributions to Mineralogy and Petrology, 115, 369-383.

Yin, A., Manning, C.E., Lovera, O.M., Menold, C., Chen, X. \& Gehrels, G., 2007. Early Paleozoic tectonic and thermomechanical evolution of ultrahigh-pressure (UHP) metamorphic rocks in the Northern Tibetan Plateau, Northwest China. International Geology Review, 49, 681-716.

\section{SUPPORTING INFORMATION}

Additional Supporting Information may be found in the online version of this article at the publisher's web site:

Figure S1. Zircon CL images and LASS ICPMS spot analysis locations for sample 6-2.1.

Figure S2. Zircon CL images and LASS ICPMS spot analysis locations for sample 6-14.

Figure S3. Zircon CL images and LASS ICPMS spot analysis locations for sample 6-1.

Figure S4. Zircon CL images and LASS ICPMS spot analysis locations for sample 6-7.

Table S1. Representative major-element mineral compositions measured by electron microprobe from the Jættedal complex gneiss.

Table S2. U-Pb isotopic data from LASS ICPMS analyses on Jættedal complex zircon.

Table S3. REE concentration data from LASS ICPMS analyses on Jættedal complex zircon.

Received 15 February 2015; revision accepted 22 August 2015. 